\title{
APPORTIONING LOSS AFTER DISCHARGE OF A BURDENSOME CONTRACT: A STATUTORY SOLUTION*
}

WhEN a court excuses parties to a contract from performance because fulfillment of contractual obligations has become intolerably burdensome, ${ }^{1}$ it then must face the problem of how to deal with losses suffered by the parties. ${ }^{2}$ Such losses may be divided into three categories. First, either party may lose his expectation-what he anticipated from the other party's full performance." Second, either party may have made expenditures in reliance on the contract 4

*An earlier version of this Comment was submitted in satisfaction of the writing requirement of the Yale Law School's Divisional Program, Commercial Transactions Division, 1959-1960. The Law Journal wishes to thank Professors Ellen A. Peters and Grant Gilmore for bringing this paper to the Editors' attention.

1. This Comment will make no attempt to discuss the substantive doctrines which courts use to discharge burdensome contractual duties. The doctrine most frequently encountered in the United States is "impossibility;" a party will not be compelled to perform or to answer in damages for failing to perform a task which is objectivcly impossible. See 6 Corbin, Contracts $\$ \$ 1325,1332$ (1951); 6 Wiluiston, Contracts $\$ 1932$ (rev. ed. 1938). Impossibility often is caused by destruction of the specific thing on which a contract was based. See, e.g., Squillante v. California Lands, Inc., 5 Cal. App. 2d 89, 42 P.2d 81 (Dist. Ct. App. 1935) ; Nitro Powder Co. v. Agency of Canadian Car \& Foundry Co., 233 N.Y. 294, 135 N.E. 507 (1922); UniforM CoMmercinl Code \& 2-613; Uniform SALEs ACT $\$ \$ 7,8$. Supervening illegality of promised performance will also occasion discharge by impossibility. See Eastern Expanded Metal Co. v. Webb Granite \& Constr. Co. 195 Mass. 356, 81 N.E. 251 (1907). "Impossibility" has on occasion been expanded to excuse performance that is not actually impossible but only burdensome. "In matters of business a thing is said to be impossible when it is not practicable, and a thing impracticable when it can only be done at an excessive or unreasonable cost." Moss v. Smith, 9 C.B. 94, 103, 137 Eng. Rep. 827, 831 (1850); see 6 Corbin, Contracts $§ 1333$ (1951) ; RestateMENT, CONTRACTS $§ 454$ (1932).

A second doctrine used by courts to excuse promisors from performing burdensome duties is "frustration of purpose." See 6 CoRBIN, op. cit. supra $\$ \$ 1353-61$; RESTATEMENT, Contracts $\S 288$ (1932). But see Anderson, Frustration of Contract-A Rejected Doctrine, 3 DE PAUL L. Rev. 1 (1953).

For discussion of how European countries treat burdensome contracts, see Drachsler, Frustration of Contract: Comparative Law Aspects of Remedies in Cases of Suprocning Illegality, 3 N.Y.L.F. 50 (1957) ; Rodhe, Adjustment of Contracts on Account of Changed Conditions, in 3 Scandanavian Studies in Law 153 (1959); Smit, Fristration of Contract: A Comparative Attempt at Consolidation, 58 CoLun. L. REv. 287 (1958).

2. Although any contract may have three or more parties, all of whom have suffercd loss, for the sake of simplicity this Comment will generally treat all contracts as two-party agreements. The same problems are involved regardless of the number of parties.

3. See Fuller \& Perdue, The Reliance Interest in Contract Damages: 1, 46 Y YLE L.J. $52,74,78$ (1936). Loss of an expectation includes not only loss of the actual performance due but also loss of any damages in lieu thereof.

4. See Fuller \& Perdue, The Reliance Interest in Contract Damages (pts. 1-2), 46 YALE L.J. 53, 373 (1936-1937) (reliance interest in relation to impossibility discussed at 
which, in order to be considered losses, must be nonrecoverable. If, for example, $A$ contracts to sell widgets to retailer $B$ and prior to the transfer of title full performance is discharged, ${ }^{5} A$ 's expenditures in acquiring or manufacturing the widgets are nonrecoverable expenses (and thus losses) if he cannot dispose of the goods to anyone else. ${ }^{\circ}$ Reliance losses may be subdivided into essential and incidental reliance losses. ${ }^{7}$ An essential reliance loss is a nonrecoverable expenditure necessary to the fulfillment of the promised performance ${ }^{8}$-in the above example, the cost to $A$ of purchasing or manufacturing the widgets. An incidental reliance loss is any nonrecoverable expenditure made in reliance on the contract other than an essential reliance loss ${ }^{\circ}$-in the above example, the cost to $B$ of advertising the widgets for resale to consumers. The third type of loss-very often the key which opens the door to discharge ${ }^{10}$ -results from the destruction of property. When the widgets are destroyed, the seller may be excused from his duty to deliver them; ${ }^{11}$ when the building burns down, the painter may be excused from his duty to paint it. ${ }^{12}$ Although the building was not bought in reliance on the contract and the widgets may have been in a stock accumulated before the contract of sale was made, ${ }^{13}$ destruction of this property was the burdensome event which gave rise to discharge, and a court seeking an equitable result may wish to consider the loss resulting therefrom as well as expectation and reliance losses.

379-82). Others have adopted the Fuller and Perdue "reliance" terminolog: when examining loss from impossible and frustrated contracts. Wirliasrs, LAw Rerozas (Frustrated Contracts) Act, 1943, at 9 (1944); Comment, 18 U. Chi. L. Rev. 153 (1951); Comment, 46 MIICH. L. REv. 401, 406-07 (1948).

5. UNIFORM SALES ACT $\$ 63$, enacted in the majority of states, see 1 UNiforss Laws Ans. XV (1950), provides that after title has passed to the buyer, the seller has a right to recover the price of the goods. Thus, there can be no discharge once title has passed.

6. If the widgets can be sold by $A$ after discharge only as scrap, then the salvage value should be deducted from $A$ 's expenses to determine $A$ 's loss.

7. Fuller \& Perdue, stipra note 4 , pt. 1, at 78.

8. Fuller and Perdue, ibid., include in the category of "essential reliance" such changes of position as foregoing the opportunity to enter other profitable contracts. Loss resulting from such a foregone opportunity is coextensive with the expectation loss. See note 28 infra and accompanying text.

9. Though unlikely, essential and incidental reliance expenses may be coniused. See Butler v. Moore, $68 \mathrm{Ga}$. 780, 782-83 (1882) (seemingly incidental expenses computed as damages under a statute which precluded compensation for "any collateral enterprise entered into in contemplation of the contract") ; Fuller \& Perdue, sipra note 4, pt. 1, at 92.

10. This Comment uses the term "discharge" to mean excusing a party from fulfilling the terms of the contract because the performance would be burdensome.

11. E.g., Uniforar Commierctal Code $\S 2-613$; Untrorar Sules Act $\S \S 7,8$; ef. Kirtley v. Perham, 176 Cal. 333, $168 \mathrm{Pac} .351$ (1917); Baker v. Brown \& Thomas Auto Co., 101 Conn. 575, 126 Atl. 703 (1924); Libman v. Levenson, 236 Mfass. 221, 12S N.E. 13 (1920).

12. E.g., Butterfield v. Byron, 153 MFass. 517, 519, 27 N.E. 667, 667-68 (1891).

13. If the widgets are part of a stock in existence when the contract was made, they cannot be reliance expenses because they were not in fact bought in reliance on the contract. 
A court which has discharged full performance of a contract can adopt five general approaches to the treatment of loss. (1) Conditions may be left as they are at the time of discharge, so that a party who has sustained any type of loss must bear it and a party who has gained any benefit may keep it..14 (2) A party may be required to disgorge benefit accruing to him from reliance ex. penditures made by the other. ${ }^{15}$ Under this "restitutionary" approach, nonrecoverable reliance expenses not benefiting another party remain losses to the party incurring the expense. ${ }^{16}$ (3) A party may be allowed to set off some or all of the losses he has suffered against the value of any benefit received from the performance of the other panty. Losses exceeding the value of any benefit received are sustained by the party who has suffered them. ${ }^{17}$ To the extent that losses are less than or equal to the value of benefit received, this approach allows the court equitably to divide losses between the parties. (4) All or some of the losses may be divided between the parties without regard to any benefit either or both may or may not have received. This approach allows the court equitably to apportion loss without the inhibition imposed by a requirement that loss be set off against correlative benefit. ${ }^{18}$ (5) The court may adjust contractual obligations of the parties in order to minimizc the total loss of both $;{ }^{19}$ new obligations would be substituted for the original

14. This rule, once prevalent in England, is represented by Chandler v. Webster, [1904] 1 K.B. 493 (C.A.) (downpayment made on frustrated contract could not be recovered); Appleby v. Myers, L.R. 2 C.P. 651 (1867) (although not in breach, a party could not recover for partial performance of an entire contract). In the United States this approach has long been known as the "English" rule. See Keeling v. Schastey \& Vollmer, 18 Cal. App. 764, 766, 124 Pac. 445, 446 (Dist. Ct. App. 1912) ; Butterfield v. Byron, 153 Mass. 517, 522, 27 N.E. 667,668 (1891). It has, however, been cited as applicable by some American courts. See Huyett \& Smith Co. v. Edison Co., 167 Ill. 233, 241, 47 N.E. 384, 387 (1897) (alternative holding); Siegel v. Eaton \& Prince Co., 165 Ill. 550, 557-58, 46 N.E. 449, 451 (1897) (dictum) ; cf. Pabst Brewing Co. v. Howard, 211 S.W. 720 (Mo. Ct. App. 1919). For divcussion of the present English law, see notes 68-86 infra and accompanying text.

15. E.g., Ontario Deciduous Fruit-Growers' Ass'n v. Cutting Fruit Packing Co., 134 Cal. 21, 66 Pac. 28 (1901) ( a buyer who accepted partial delivery of peaches had to pay for them even though it was impossible for the seller to deliver the full quantity promised): cf. Restatement, Contracts \$ 468 (1932).

16. See, e.g., Fibrosa Spolka Akcyjna v. Fairbairn Lawson Combe Barbour, Ltd., [1943] A.C. 32, 49-50, 54 (seller, who partially manufactured machines but was unable to deliver them because of the war, could recover nothing for the expenses he incurred although he was forced to return a downpayment made by buyer).

17. See Law Reform (Frustrated Contracts) Act, 1943, 6 \& 7 Geo. 6, c. 40, $\$ 1$ (2)(3), set out in text at note 78 infra.

18. American courts do not and are not likely to split loss in discharge cases. Sec note 91 infra and accompanying text. Loss splitting, however, has been suggested by legal writers as the most equitable solution to these problems. See Sharpe, Promissory Liability: II, 7 U. Cer. L. Rev. 250, 269 (1940) ; Comment, 18 U. Crr. L. Rrv. 153, 157-63 (1951) ; Comment, 46 Mich. L. REv. 401, 421 (1948).

19. Adjustment of contractual obligations in burdensome performance sittations hak become common in some European nations during the first half of the twentieth century. See Cohn, Frustration of Contract in German Law, 28 J. CoMp. LEG. \& INT'L L. (3d ser.) pt. III, at 15, 19-25 (1946) ; Drachsler, supra note 1, at 71-79; Rodhe, supra note 1, at 
ones and enforced as if they were the terms of the contract. Loss remaining after performance of the modified obligations could then be apportioned.

Selection of the most appropriate method of treating losses suffered by parties to a discharged contract depends upon the decisionmaker's concepts of fairness and is intimately related to the fact of discharge and the circumstances which give rise to it. ${ }^{20}$ Equitable considerations suggest the soundness of the current United States rule that a party may not retain the benefit accruing to

181-90. See generally Smit, supra note 1. Because twenteth-century Germany has been swept by uncertainty and self-made catastrophe, ranging from revolution to war, from inflation to extreme deflation, the law of contractual frustration and hardship is probably better developed there than elsewhere. See Cohn, sipra note 1, at 15; Rodhe, sipro note 1, at 153. German jurisprudence's chief springboard into the field of contractual modifieation seems to have been the doctrine of Geschaffisgrmallage, or "contractual basis," introduced in Oertarann, Die Geschäftsgrundlage, ein neuer Rechtsbegriff (1921). See Cohn, supra at 20. From this doctrine that, when the basis of a contract lapses, there is no longer any reason to enforce it, the concept of Ausgleichsanspruch or "claim for adjustment" developed. See Cohn, stpra at 22. Actually, the Reichsgericht broke away from its refusal to tamper with contractual obligations before Oertmann's treatise on Geschäftsgrmudloge was published in 1921. See S. Sp. G. m.b. H. v. J.G., Reichsgericht (VI. Zivilsenat) Sept. 21, 1920, 100 Entscheidungen des Reichsgerichts in Zivilsachen [hereinafter cited as R.G.Z.] 129 (Ger.) (court acceded to plaintiff landlord's demand to increase rent when inflation made the value of steam which had been supplied to tenants disproportionately large). When adjustment became popular, however, it seems to have been closely tied to Geschäftgrimdlage and notions of good faith. See, e.g., S.R. v. B., Reichsgericht (VI. Zivilsenat), Jan. 30, 1928, 119 R.G.Z. 134, 138 (Ger.); S.G. v. H., Reichsgericht (V. Zivilsenat), Feb. 10, 1926, 112 R.G.Z. 329, 333 (Ger.); Cohn, supra at 22; Smit, supro note 1, at 298. Furthermore, "judicial adaptation of the contract to the new conditions of life became more and more the rule and termination by way of recission the exception. It was felt that the latter was in effect the more radical solution." Coln, sipra at 22-23. Adjustment of obligations is still the rule in Germany. In fact, it has been reinforced by a decree (1939) and an act (1952) both providing for the administration of Veriragshilfe or "judicial assistance." For the history of these and other present developments in Germany, see Drachsler, supra note 1, at 72-77. See generally, Exweccerus-Lemarax: RECHT DER SCHULDVERHÄLTNISSE § 41 (15th ed. 1958).

Adjustment of contractual obligations has not been unique to Germany. For a diseussion of adjustment in Scandinavian countries see Rodhe, supra note 1, at 185-86. For Swiss adjustment, see Deschenaux, La Revision des Contrats en Droit Suisse, $30 \mathrm{~J}$. Cossp. LEG. \& INT'L L. (3d ser.) pt. III, at 55, 64-67 (1948). Two interesting proposed statutory provisions were Proposal for Changes in the Geraran Crvi Code $\$ 24$ (1935) and Hungarian Proposal for a CriII Code $\$ 1150$ (1928), both of which are quoted in Rodhe, sipra note 1 , at 188 .

American courts do not generally openly adjust contractual obligations. But see Transbay Constr. Co. v. San Francisco, 35 F. Supp. 433 (N.D. Cal. 1940), where plaintiff recovered more than the contract price for fulfilling his contractual obligation to excavate for the foundation of Hetch-Hetchy dam. The excaration amounted to 84,000 yards when both parties anticipated it would amount to 30,000 , and it took a year longer to accomplish than either party anticipated. The court said it was granting plaintiff quantum meruit above the contract price.

20. The substantive law of discharge and placement of loss (with which this Comment is primarily concerned) are closely related. A decision not to discharge is often explicitly a decision to make one party sustain all losses. See, e.g., Ahlgren v. Walsh, $173 \mathrm{Cal}$. 
him from the losses of another. ${ }^{21}$ Additionally, in dealing with those losses which are not coupled with gain to the other party, a court normally cannot resort to damage principles of assumption of risk ${ }^{22}$ or fault. ${ }^{23}$ Because the occasion for discharge is ordinarily an externally caused, unknown, ${ }^{24}$ or unanticipated event, ${ }^{25}$ neither party will have assumed the risk in the vast majority of cases and neither party will be a "wrongdoer" to whom the court can easily assign responsibility for loss. Thus, only innocent parties will bear losses resulting from a contract discharged as burdensome, and therefore equitable consider-

27, 31, 158 Pac. 748, 750 (1916) ; Stees v. Leonard, 20 Minn. 494, 505-06 (1874); Fuller \& Perdue, supra note 4, pt. 2, at 381 ; Patterson, The Apportionment of Business Rishs Through Legal Devices, 24 CoLuM. L. REv. 335, 348-53 (1924).

21. See notes $34-35$ infra and accompanying text.

22. A case in which assumption of risk was employed was Shelton v. Tuttle Motor Co., 223 N.C. 63, 25 S.E.2d. 451 (1943), where the court found that plaintiff had assumed the risk and thus could not recover his downpayment although return performance could not be had. Assumption of risk will often arise when discharge itself is in issuc. Sec Beacon Tool \& Mach. Co. v. National Prods. Mfg. Co., 252 Mass. 88, 147 N.E. 572 (1925) ; McQuaid v. Michou, 85 N.H. 299, 301-02, 157 At1. 881, 883 (1932) (promisors consciously agreed to perform objectively impossible tasks and the courts ruled no discharge). On the difficult problem of determining when risk is assumed, see 6 Conurs, Contracts $\S \S 1254,1327,1328$ (1951) ; Comment, 46 Mich. L. Rev. 401, $402-05$ (19-18).

23. When $B$ is responsible for the event preventing $A$ from completing performance, $A$ may sue $B$ for breach and recover damages. Everding \& Farrell v. Gebhardt Lutmber Co., 86 Ore. 239, 247-49, 168 Pac. 304, 307 (1917) ; Bradley v. Nevadn-Cal.-Ore. Ry, 42 Nev. 411, 420-21, 178 Pac. 906, 908 (1919) ; Patterson v. Meyerhofer, 204 N.Y. 96, 101, 97 N.E. 472, 473 (1912); see 4 Corbin, Contracts \& 947 (1951); Restatement, ConTRACTS § 315(1) (1932); cf. Parker v. Stevens, 157 Ark. 89, 247 S.W. 393 (1923); Tricolo v. Centalanza, 2 N.J. Misc. 1157, 126 Atl. 741 (Sup. Ct. 1924).

When courts excuse performance, they almost always note that no party was at fatt for causing the event which occasioned discharge. See, e.g., Keeling v. Schastey \& Vollmer, 18 Cal. App. 764, 766, 124 Pac. 445, 446 (Dist. Ct. App. 1912) ; Young v. City of Chicopee, 186 Mass. $518,519,72$ N.E. 63 (1904).

24. Performance promised may have been impossible or burdensome before the contract was entered. If the promisor did not know of this difficulty before he committed himself, he is excused from performing. E.g., Williams v. Miller, 68 Cal. 290, 293, 9 Pac. 166, 168 (1885) ; LeRoy v. Jacobosky, 136 N.C. 443, 459, 48 S.E. 796, 801 (1904); Banuau v. Graeff, $186 \mathrm{~Pa} .648,40$ Atl. 805 (1898) ; Paxton Lumber Co. v. Panther Coal Co., 83 W. Va. 341, 348-53, 98 S.E. 563, 566-68 (1919). The rules used in the foregoing cases were those of "antecedent impossibility" and "mutual mistake." The counterrule to these, by which courts can enforce impossible obligations, is "assumption of risk." See note 22 supra.

25. Unless the burdensome event is unanticipated, discharge will not be forthcoming. E.g., Lloyd v. Murphy, $25 \mathrm{Cal}$. 2d 48, 153 P.2d 47 (1944). In Lloyd, defendant-lessec claimed his lease was frustrated because the Second World War restricted his ability to acquire automobiles for resale and that he entered the lease for the purpose solely of selling automobiles. The court, speaking through Mr. Justice Traynor, did not accept the defendant's argument: "[I]t cannot be said that the risk of war and its conscquences necessitating restriction of the production and sale of automobiles was so remote a contingency that its risk could not be foreseen by defendant." Id. at 55-56, 153 P.2d at 51 ; accord, Northern Pac. Ry. v. American Trading Co., 195 U.S. 439, 467-68 (1904); sco 6 Corbin, Contracts $\S 1354$ (1951); $c f$. Madeirense Do Brasil v. Stulman-Emrick Li'ubor Co., 147 F.2d 399, 403 (2d Cir. 1945). 
ations further suggest that at least some nonbenefiting losses should not be sustained by one party, but should be evenly shared. ${ }^{20}$ Indeed, division of los: may be additionally beneficial, since each party may be able to bear part of it "without serious consequences, when the whole loss might come close to ruining him."27

But once the idea that some losses should be shared is accepted, another problem arises, one even less susceptible to a satisfactorily articulated answer: What losses are to be shared or taken into account in determining the proportionate shares of the parties? Analysis indicates that losses resulting from out-of-pocket expenditures made in reliance upon the contract or from destruction of property should be included in an apportionment formula, while expectation losses should never be shared. ${ }^{28}$ Reliance and property losses fall solely on one party, no less innocent than his opposite. Apportionment of these losses, which may be thought of as the residue of a discharged contract, provides a method whereby both parties suffer more or less equally from the misfortune which excused performance. Apportionment of expectation losses, on the other hand, would be inconsistent with, rather than complementary to, discharge itself. By discharging a contract a court is in effect saying that a party cannot enforce the full performance due him, in other words, his expectation, ${ }^{20}$ either specifically or through damages. ${ }^{30}$ For the same court then to say that

26. See Williaxis, Law Reform (Frustrated Contracts) Act, 1943, at 35-40 (1944); Sharp, Promissory Liability: II, 7 U. CHI. L. Rev. 250, 269 (1940); Williams, The End of Chandler v. Webster, 6 Miod. L. REv. 46, 50 (1942); Comment, 18 U. Crr. L. Rev. 153, 157-63 (1950); Comment, 46 1fice. L. REv. 401, 421 (1948).

27. Williasis, Law Reforas (Frustrated Contracts) Act, 1943, 35-36 (1944).

28. Exclusion of expectation loss from an apportionment formula necessarily precludes compensation for certain change-in-position reliance losses coevtensive with the expectation loss, such as those incurred by foregoing opportunities to enter similar cintracts. See Fuller \& Perdue, supra note 4, pt. 1, at 74, 75.

29. See Butterfield v. Byron, 153 Mass. 517, 27 N.E. 667 (1891); Fuller \& Perduc, supra note 4, pt. 2, at 379; Comment, 46 MIICr. L. REv. 401, 412 (1948).

30. Of course, when one party has fully performed, and the court follows the appruach of allowing gains or losses to remain where they fall at the time of discharge, the other party's expectation is not lost. In Civil Serv. Coop. Soc'y v. General Steam Nav. Cu., [1903] 2 K.B. 756 (C.A.), plaintiff prepaid the complete contraet price before the event arose which "frustrated" the purpose of the contract. The Earl of Halsbury, L.C., said "that the defendants had a right to retain what they had been paid, and that the parties on either side were excused from any further performance of the contract." Id. at 763 . Although a holding of discharge was not necessary in this case, it would be difficult to say that the contract was not discharged because of the above quoted language and the same court's former decision in Krell v. Henry, [1903] 2 K.B. 740 (C.A.). In Krsll, cancellation of the coronation of Edward VII occasioned discharge of a contract to hire a liat, at especially high rates, from which the hirer could view the coronation procession. In Civil Service, the cancellation of the same coronation rendered valueless the plaintifi's contract to hire a ship from which the coronation naval review could be watched.

It is perhaps amusing to note that while the burdensome-contract law of Germany had its twentieth-century development in cases involving war, inflation and other disasters. see note 19 supra, the event which gave twentieth-century English courts their great opportunity to develop the law of discharge was the illness of Edward VII. 
the excused party must participate in the other's expectation loss would be only to award partial damages in another guise, a solution not only repugnant to discharge, but, in that context, unfair. Assuming, as this Comment does throughout, that it was fair for the contract to have been discharged, it follows that it would be unfair for any payment which in any way represents performance to be forthcoming from one party to the other. Secondly, since the fortuity of actual reliance expenditures provides no generally applicable guides for the placement of loss, it seems fairest to split loss according to equal innocence. The amount of reliance loss either party incurs depends on the time elapsed before the occurrence of the event occasioning discharge; in most contracts both parties will have some reliance expenditures. If reliance loss is left where it falls, who incurs the loss and how much is incurred are as fortuitously unfortunate as the fact that the contract cannot be performed. Further, American courts have, by mechanical rules unrelated to notions of fairness, sometimes shifted and sometimes refused to shift reliance loss. Upon discharge, therefore, a court is faced with reliance loss, the amount of which is determined by chance, two innocent parties, and no guides (except mechanical ones) to identify the party to bear it. Apportioning these losses marks the minimal change in present law necessary to systematize somewhat the treatment of loss after discharge of burdensome contracts. When a court is faced with expectation loss, on the other hand, the real value of the contract to each party will always be represented by his expectation, and is dependent not on when the discharging event occurs or on who moves first, but on the market and upon the party's ability and position. Upon discharge, each party, by losing his expectation, loses the entire value of the contract to him. Thus, expectation loss may be said already to be equal between the parties, realistically if not arithmetically; it is entirely reasonable for each party to lose upon discharge all he stood to gain upon performance. Moreover, apportioning expectation losses may solve too much; they, unlike reliance losses, have always been borne by the party incurring them. Finally, already-expended reliance losses may be more substantial, although not in an economic sense. than lost profits and are certainly amenable to precise preapportionment evaluation, while the actual value of lost expectations, unrealized and perhips. conjectural, will often be accurately reflected in an allocation scheme only if each party bears his own.

\section{The American Approach}

American courts which have discharged contracts as burdensome do not, as has been indicated, explicitly divide loss; instead they have ordinarily restricted themselves to a restitutionary formula based on the idea that no one should be enriched by another's misfortune. ${ }^{31}$ All losses lie where they fall at

31. See 6 Corbin, Contracts $\$ \S 1367-72$ (1951) ; KeEner, QUAsi-Contracts 241-58, 292-98 (1893); 6 WILliston, Contracts $\$ 1977$ (rev. ed. 1938); WOODWARd, QUasiContracts $\$ \S 1-34,109-31$ (1913). 
the time of discharge, except that each party must pay for benefits received from the essential reliance expenditures of the other. ${ }^{32}$ Since incidental reliance expenditures are not incurred in fulfilling promised performance, benefit accruing therefrom is not compensable. ${ }^{33}$ Restitution is completely satisfactory when all losses are essential reliance losses and result in commensurate gains translatable into pecuniary value. If, for example, buyer $B$, who contracts to purchase whiskey, is unable to obtain a liquor license, he can recover any downpayment made to seller $A .^{34}$ Assuming that $A$ can sell the whiskey elsewhere, both parties lose only their expectations. Similarly, when one renduring services which benefit another dies uncompensated after partial pr:riormance, the deceased's estate may recover the reasonable value of the services performed. ${ }^{35}$ In these cases, if no loss remains after restitution, no need exists

32. See Restatearent, Contracts $\$ 468$, comment $d$ (1932), which states the typical non-sequitur: "Since there is no fault on either side, the loss due to impossibility or frustration must lie where it falls. Neither party can be compelled to pay for the other's disappointed expectations. But, on the other hand, neither can be allowed to profit by the situation. He must pay for what he has received." Although it is true that equitable considerations militate against one party profiting from another's loss, it does not follow: that nonbenefiting reliance loss should lie where it falls. See notes $29-30$ sipro and ascompanying text.

33. If, for example, a retailer successfully advertises a manufacturer's gosds, the manufacturer would be benefited, but unless the retailer has a contractual obligation to advertise, he would have no right against the manufacturer. Cf. United States v. Pacific R.R., 120 U.S. 227, 239-40 (1887) ; Davidson v. Westchester Gas Light Co., 99 N.Y. 558, 566-67, 2 N.E. 892, 895 (1885). See also Woodward, Quast-Contracts $\$ 49$ (1913).

34. Panto v. Kentucky Distilleries \& Warehouse Co., 215 App. Div. 511, 214 X.Y. Supry. 19 (1926) ; accord, Kirtley v. Perham, 176 Cal. 333, 168 Pac. 351 (1917); Conlin v. Osborn, 161 Cal. 659, 666, 120 Pac. 755, 759 (1911) ; Potts Drug Co. v. Benedict, 156 Cal. 322, 334, 104 Pac. 432, 437 (1909); Orgren v. Inner Harbor Land Co., 83 Cal. App. 197, 256 Pac. 607 (Dist. Ct. App. 1927); Wong Ah Sure v. Ty Fook, 37 Cal. App. 465, 174 Pac. Gf (Dist. Ct. App. 1918) ; Bowser v. Chalifour, 334 Afass. 34S, 352-53, 135 N.E.2d 643, G15 (1956) ; Cochrane v. Forbes, 257 Mass. 135, 150, 153 N.E. 566, 569 (1926); Libman v. Levenson, 236 Mass. 221, 128 N.E. 13 (1920); Tenner v. Retlaw Dev. Corp., 163 Mise. 248, 295 N.Y. Supp. 31 (Sup. Ct. 1936).

Parties to a discharged contract must also pay for benefit received from periormance other than downpayment. Mineral Park Land Co. v. Howard, 172 Cal. 289, 156 Pac. 453 (1916) ; Ontario Deciduous Fruit-Growers' Ass'n v. Cutting Fruit Paching Co., 13+ Cal. 21, 66 Pac. 28 (1901) ; Eastern Expanded Metal Co. v. Webb Granite \& Constr. Co., 195 Mass. 356, 81 N.E. 251 (1907) ; Tanner v. Childers, 108 Utah 455, 465-66, 160 P.2d 965, 970 (1945); Snipes Mountain Co. v. Benz Bros., 162 Wash. 334, 298 Pac. 714 (1931).

For a case in which restitution in kind was ordered upon discharge, see Fulton, Hensley \& Co. v. Thompson, 18 Tex. 278 (1857).

35. Roe v. Sears, Roebuck \& Co., 132 F.2d 829, 832 (7th Cir. 1943); MIulqueen v. Commissioner, 65 F.2d 365 (2d Cir. 1933); White v. White, 274 III. App. 531 (1934); Morton v. Forsee, 249 Mo. 409, 418-26, 155 S.W. 765, 767-74 (1913); Stein v. Shaw. 6 N.J. 525, 79 A.2d 310 (1951); Buccini v. Paterno Const. Co., 253 N.Y. 256, 170 N.E. 910 (1930) ; Sargent v. McLeod, 209 N.Y. 360, 103 N.E. 164 (1913); Lacy v. Getman, 119 N.Y. 109, 23 N.E. 452 (1890); In re Scanlon's Estate, 150 N.Y.S.2d 511 , 517 (Surr. Ct. 1956) (dictum); In re Lake's Estate, 123 N.Y.S.2d 307 (Surr. Ct. 1953); In re Levy's Will, 207 App. Div. 183, 188, 201 N.Y. Supp. S18, 822 (1923) ; City of Barnsdall v. Curnutt, 
for further compensation. But when all losses do not result in commensurate gains, strict adherence to the restitutionary rule may produce unjust results. Assume that $A$ in the above example, pursuant to agreement, was manufacturing display racks to $B$ 's specifications when the contract was discharged. Since $B$ never used or received the racks, restitution is inapplicable. ${ }^{\text {au }}$ Although neither party contractually assumed the risk and neither caused the loss, $A$ bears the entire reliance loss and $B$ loses only his expectation.

Perhaps aware of the inequities which may result from an unaclorned restitutionary rule, some American courts shift nonbenefiting essential reliance loss by attenuating or ignoring the concept of benefit. Thus, "benefit" is transmuted from net gain having pecuniary value ${ }^{37}$ into acts and services which are part of a promised performance, regardless of whether the promise gains anything from the transaction. ${ }^{38}$ Attenuation of benefit appears most frequently in repair and alteration cases in which the discharging event is a clisaster not only rendering full performance impossible but destroying work alreacly done. Suppose, for example, that a carpenter, $C$, is building a bar into the house of a homeowner, $O$, and the house is destroyed by lightning before completion of the job. Can it be said, for the purposes of applying the restitutionary rule of recovery, that $C$ 's partial performance accrued to $O$ 's benefit? Many American courts would emphatically answer "Yes."'so Some would

198 Okla. 3, 174 P.2d 596 (1945); Landa v. Shook, 87 Tex. 608, 30 S.W. 536, aff'd on retrial, 31 S.W. 57 (Tex. Civ. Ct. App. 1895); O’Brien v. Gilleland, 79 Tex. 602. 15 S.W. 681 (1891).

The restitutionary rule also applies when personal service contracts are discharged for reasons other than death of a party. Boardman v. Christin, 65 Cal. App. 413, 224 Pac. 97 (Dist. Ct. App. 1924) (minor came of age and discharged attorney previously hired for him); Harrington v. Fall River Iron Works Co., 119 Mass. 82 (1875) (sickness); Wolfe v. Howes, 20 N.Y. 197 (1859) (sickness); cf. Jones v. Judd, 4 N.Y. 411 (1850).

36. Cf. Binz v. National Supply Co., 105 S.W. 543, 545 (Tex. Civ. Ct. App. 1907) : Carroll v. Bowersock, 100 Kan. 270, 164 Pac. 143 (1917); Wallace Studios, Inc. v. Brochstein's, Inc., 297 S.W.2d 218, 223-24 (Tex. Civ. App. 1956) (dictum). See also Fibrosa Spolka Akcyjna v. Fairbairn Lawson Combe Barbour, Ltd., [1943] A.C. 32, 49-50, 54, 63.

37. This definition is often used in quasi-contractual cases. Comment, $46 \mathrm{Mtcr}$. L. REv. 543, 545 (1948) ; see, e.g., Independent Elec. Lighting Corp. v. Brodsky \& Co., 118 Misc. 561,194 N.Y. Supp. 1 (Sup. Ct. 1922) ; Ryan \& Associates v. Century Brewing Ass'n, 185 Wash. 600, 55 P.2d 1053 (1936). Compare Phillips v. Homfray, 24 Ch. D. 439, 455 (1883).

38. See Whelan v. Ansonia Clock Co., 97 N.Y. 293 (1884); cases cited note 39 infra: cf. Vickery v. Ritchie, 202 Mass. 247, 88 N.E. 835 (1909). Compare Restatement, ConTRACTS $\$ 468$, comment 3 (1932).

39. Lord v. Wheeler, 67 Mass. (1 Gray) 282 (1854); Anderson v. Shattuck, 76 N.H. 240, 81 At1. 781 (1911) ; F. M. Gabler, Inc. v. Evans Labs., Inc., 129 Misc. 911, 913, 223 N.Y. Supp. 408, 410 (Sup. Ct. 1927); cases cited notes 40,41 infra.

Many repair and alteration cases do not specifically mention benefit or the related concepts of property passing, see note 40 infra, and delivery, see note 41 infra. It is helpful, however, to catalogue these cases with those in which benefit is attenuated because it is in terms of benefit that the scholarly disputes about this matter have been waged. Sce note 43 infra. "The principle [in the cases which do not mention benefit] seems to be that when, under an implied condition of the contract, the parties are to be excused from performance if a certain event happens, and by reason of the happening of the event it becomes 
find benefit in the passage to $O$ of title to the materials permanently attached to the house $;^{40}$ others would say $O$ benefited because he accepted the work done.+1 Whichever doctrinal route is followed, the result generally is the same: $i$ recovers the value of materials permanently attached and the labor attributalsle to attachment; he suffers the loss of materials not permanently attached and the expenses of planning the uncompleted performance."2 Arguably, $O$ benefited from $C$ 's partial performance in that he might have sold the house prior to the completion of the contract at a sales price enhanced by C's labor. ${ }^{48}$ Similarly, $O$ might have insured his property in such a manner that the value of $C$ 's partial performance would be recoverable on a policy claim against the

impossible to do that which was contemplated by the contract, there is an implied assum: psi! for what has been properly done . ..." Butterfield v. Byron, 153 MIass. 517, 523, 27 N.E. 667, 669 (1891) ; accord, Keeling v. Schastey \& Vollmer, 18 Cal. App. 764, 766, 124 Pac. 445, 446 (Dist. Ct. App. 1912) ; Tripp v. Henderson, $158 \mathrm{Fla}$ 442, 28 So. $2 \mathrm{~d} 857$ (1947): Haynes, Spencer \& Co. v. Second Baptist Church, 88 Mo. 285, 292 (1885) ; Acme Plumbing \& Heating Co. v. Hirsch, 121 Neb. 134, 236 N.W. 137 (1931); Bailey v. Brown, 9 Ohio C.C.R. 455, 460-61 (Cir. Ct. 1895) (dictum); Weis v. Devlin, 67 Tex. 507, 3 S.W. 726 (1887) ; Albus v. Ford, 296 S.W. 981 (Tex. Civ. Ct. App. 1927) (dictum); Halsey v. Waukesha Springs Sanitarium Co., 125 Wis. 311, 314, 104 N.W. 94, 95 (1905) ; cf. Rawson v. Clark, 70 Ill. 656 (1873) (although owner not actually at fault he was considered to be in breach for allowing his building to burn down); Niblo v. Binsse, 1 Keyes 476 (N.Y. 1864) (owner not at fault but considered in breach-nevertheless, recovery same as in no-breach cases); Hollis v. Chapman, 36 Tex. 1 (1872).

The rules of the foregoing cases apply to chattels as well as real property. See Whelan v. Ansonia Clock Co., 97 N.Y. 293 (1884); Rhodes v. Hinds, 79 App. Div. 379, 79 N.Y. Supp. 437 (1903).

40. Hayes v. Gross, 9 App. Div. 12, 13, 40 N.Y. Supp. 1098, 1099 (1896), aff'd ans opinion below, 162 N.Y. 610,57 N.E. $1112(1900)$; accord, Dane v. Wood, 75 N.H. 3S, 70 Atl. 1081 (1908); Wilson v. Knott, 22 Tenn. 473 (1842); Hysell v. Sterling Cosl \& Mfg. Co., 46 W. Va. 158, 162, 33 S.E. 95, 96 (1899) ; cf. Young v. City of Chicopee, 186 Mass. 518, 520, 72 N.E. 63, 64 (1904) (materials "insured" to owner).

41. Matthew Constr. Co. v. Brady, 104 N.J.L. $438,442-43,140$ Atl. 433,435 (Ct. Err. \& App. 1928) ; cf. Wallace Studios, Inc. v. Brochstein's, Inc., 297 S.W.2d 218, 223-24 (Tex. Civ. Ct. App. 1956) (dictum); Binz v. National Supply Co., 105 S.W. 543, 545 (Tex. Civ. Ct. App. 1907) (dictum).

42. See Carroll v. Bowerstock, 100 Kan. 270, 164 Pac. 143 (1917); Young v. City of Chicopee, 186 Mass. 518, 72 N.E 63 (1904). But see Haynes, Spencer \& Co. v. Second Baptist Church, 88 Mo. 285 (1885) (recovery not only for fixtures attached but for those on the floor of the structure at time of destruction); F. M1. Gabler, Inc v. Evans Labs. Inc., 129 Misc. 911, 223 N.Y. Supp. 408 (Sup. Ct. 1927) (recovery for materials attached and materials in building but not attached; no recovery for materials not delivered or expenses for preparing future performance).

43. Professor Woodward argued that "every unit or particle of material which, in accordance with the defendant's wish, is irrevocably appropriated to the improvement of the defendant's property, and every stroke of labor performed upon such material or upon the property improved, constitutes a benefit to the defendant, and the failure of the defendant to use or occupy such improvement . . . clearly cannot affect the right of recovery." Woodward, QUasI-Contracts 183-S4 (1913); see Williasss, LaW Refutas (Frustrated Contracts) ACt, 1943, at 48-51 (1944). But sec Krener, Quasi-Co:trancts 253-58 (1893). 
insurance company.44 But these "benefits" are at best conjectural, depending on the facts of each case. Realistically, $O$ was unable to use or enjoy half a bar and was left with a pile of ashes. In other situations, when not even such Pickwickian benefit can be found, some courts shift nonbenefiting reliance loss simply by holding that the promisee should pay for services performed. ${ }^{45}$ In Angus $v$. Scully, ${ }^{46}$ for example, plaintiff contracted to move a house for defendant. When the building had been moved half way to its new location, it was entirely consumed by fire at some time during the night. Plaintiff recovered the fair value of the services rendered prior to the fire. The court, not attempting to find benefit to the home owner, found insteal an "implied assumpsit" requiring compensation for partial performance.

When the courts of a single jurisdiction alternately apply the strict restitutionary rule and its more liberal variations, inconsistent results may obtain. For example, if a contract has been discharged as burdensome in Texis, it appears that a builder may recover the value of his essential reliance losses without regard to benefit, while an auditor may not. In Weis v. Devlin, ${ }^{47}$ a builder contracted to remodel defendant's house. During the course of the work, the house was destroyed along with the labor and materials wrought into the house although no discernible benefit accrued to the defendant. The $W$ cis court, implying that benefit was not essential to recovery, ${ }^{48}$ apparently followed an "attenuated" or "ignore benefit" approach in order to shift the reliance loss. In West Aidit v. Yoakum County," however, the court adhered to a strict restitutionary rule of recovery. Yoakum County contracted with plaintiff to have the county books audited, the audit to take place at the county court house. Before the audit was completed, the court house and all the books and work sheets were destroyed by fire. The court held that, since the county received no benefit from plaintiff's performance, plaintiff could not recover the reasonable value of the work done. ${ }^{\tilde{0} 0}$

44. If $O$ did in fact recover insurance, little doubt exists that he has been benefited in the strictest sense of the word. See Ganong \& Chenoweth v. Brown, 88 Miss. 53, 40 So. 556 (1906) (dictum); Hysell v. Sterling Coal \& Mfg. Co., 46 W. Va. 158, 162, 33 S.E. 95, 96 (1899); Cook \& McCabe, 53 Wis. 250, 259, 10 N.W. 507, 511 (1881); c\%. Rhodes v. Hinds, 79 App. Div. 379, 79 N.Y. Supp. 437 (1903). But sec Carroll v. Bowerstock, 100 Kan. 270, 273, 164 Pac. 143, 144 (1917) (dictum to the effect that insurance is an irrelevant consideration).

45. See Moore v. Robinson, 92 Ill. 491 (1879). Such a holding may be based on a theory of implied contract, see, e.g., Stein v. Shaw, 6 N.J. 525, 79 A.2d 310 (1951), or one of quantum meruit, see Boardman v. Christin, 65 Cal. App. 413, 419, 224 Pac. 97, 99 (Dist. Ct. App. 1924); Wolf v. Altmeyer, 8 Pa. Dist. 408 (C.P. 1899).

46. 176 Mass. 357,57 N.E. 674 (1900).

47. 67 Tex. 507, 3 S.W. 726 (1887).

48. Id. at 511,3 S.W. at 728 .

49. 35 S.W.2d 404 (Tex. Com. App. 1931), aff'd on retrial, 53 S.W.2d 311 (Tex. Civ. Ct. App. 1932).

50. 53 S.W.2d at 312. The Commissioner on the first appeal seemed to take an attenuated view of benefit, 35 S.W.2d at 407 . The court on the second appeal, however, affirmed a jury finding of no benefit in spite of the fact that the jury and the trial judgc 
It is not immediately apparent why the builder's services in $H$ 'eis were more deserving of compensation than the auditor's in Yoakum County. In neither case did the defendant ultimately derive anything of pecuniary value from plaintiff's partial performance. In both, the plaintiff's work was consumed by thame. Perhaps the courts were responding sub silentio to their views of the underlying equities. In Yoakum, for example, the county did not have money to pay for the audit and apparently entered the contract only because of strong political pressure. ${ }^{51}$ These cases may therefore serve as illustrations oi ho: a court, constrained by traditional "all-or-nothing" rules of recovery, must make inconsistent doctrinal decisions to achieve what it considers to be an equitable result.52 But this vacillating technique may be inadequate to the task of justly dealing with losses in discharge cases. By emphasizing, attenuating, or ignoring the requirement of benefit, a court ordinarily must shift, rather than apportion, essential reliance loss. The shift may be complete or partial, depending on the rule used and the facts to which it is applied.".3 A shift of the entire loss may operate equitably in the rare case when an erent makes full performance sufficiently burdensome to warrant discharge but one of the parties is not entirely free from fault. ${ }^{-4}$ In most discharge cases, however, neither party is remotely responsible for the burdensome event. A partial

did not adopt the Commissioner's broad definition. In his charge, the trial judge distinguished between "benefit" and "reasonable value of the services rendered by the West Audit Company ...." $33 \mathrm{S.W}$. at 312. From this distinction, the jury must have assumed that "benefit" had to be some actual gain for the county and it was only natural that they should find no such gain.

51. See 35 S.W.2d at 406.

52. Another interesting conflict of approaches within one jurısdiction is evidenced by three Illinois cases. White v. White, 274 Ill. App. 531 (1934) ( restitutionary approach); Huyett \& Smith Mfg. Co. v. Chicago Edison Co., 167 III. 233, 47 N.E. 384 (1897) (losses should fall where they lie; at least an alternative holding); Mfoore v. Robinson, 92 IIl. 491 (1879) (nonbenefiting reliance loss compensated). A study of these cases suggests that courts of one jurisdiction may make inconsistent doctrinal distinctions as much through inadvertance as through the pursuance of equitable results. For another view of these cases, see Comment, 18 U. CHI. L. REv. 153, 155-56 (1951).

53. See Wolf v. Altmeyer, \& Pa. Dist. 408 (C.P. 1899) (shift of complete noubenefiting reliance loss); Young v. City of Chicopee, 186 Mass. 518, 72 N.E. 63 (1904) (shift vi nonbenefiting reliance loss for materials attached to structure by builder; no shift fur loss representing those materials not attached).

54. See Albre Marble \& Tile Co. v. John Bowen Co., 155 N.E. 437 (Mrss. 1959). John Bowen Co. had a construction contract with the state. After performance had begun, the contract was voided because of an imperfection in the manner of bidding. Sce Gifford v. Commissioner of Pub. Health, 328 Mrass. 60S, 105 N.E2d 476 (1952). Subcontractors had started work under the contract. The voiding of the principal contract made all the subcontracts impossible to perform. In the past few years, there have bean several suits by the subcontractors against Bowen to recover the value of periormance rendered before impossibility. See Boston Plate \& Window Glass Co. v. John Bowen Co., 335 Mass. 697, 141 N.E.2d 715 (1957) ; MI. Ahern Co. v. John Bowen Co., 334 Mlass. 36, 133 N.E.2d 484 (1956). The latest of these, and the one most clearly defining the court's position, is the Albre case, where the court stated the case before it was not one of "pure impossibility" for "defendant's involvement in creating the impossibility was greater 
shift of the essential reliance loss will accomplish equitable apportionment only by chance. Recall the above example in which $C$ was butilding a bar for $O$ when the latter's home was destroyed by lightning. When a court places the loss for labor and materials attached to the building on $O$ and the loss for materials not attached on $C$, it is splitting C's reliance loss. ${ }^{55}$ But only when the materials attached represent half the loss will the split be equal; thus apportionment is made on purely mechanical grounds unrelated to the equities.

The myopia involved in traditional rules of reoovery is most evident when the burdensome event occasioning discharge of a contract is clestruction of property. American courts rarely, if ever, talk about compensation of property loss in discharge cases. When, however, the cost or use of the clestroyed property was a reliance expenditure, a party may be compensated for it. Carpenter $C$, for example, who was building the bar into $O$ 's home when the house was destroyed, suffered a loss from the destruction of lumber he bought in reliance on the contract. To the extent that he recovers for expenditures made in reliance, he is compensated for the cost of the lumber. Similarly, the cost to a seller of obtaining or manufacturing widgets in reliance on a contract of sale may be classified on discharge for destruction as either a reliance or property loss. If a court, ignoring the title-risk-of-loss provisions of the Sales Act, compensates him for his reliance expenses, it is also compensating him for the value of the destroyed property. ${ }^{57}$ But not all property in these situations is bought or made in reliance on the contract. The above-mentioned seller may have had the widgets on hand before the contract of sale was made. A court using a remedy based solely on compensation for nonrecoverable reliance expenses might not include the widgets in its calculation of loss. Nevertheless, no difference may exist, from an equitable point of view, between the loss accrit. ing from destruction of the widgets bought in reliance on the contract and that resulting from the destruction of those which would have been bought in reliance on the contract had they not already been in stock, especially in the context of a commercial contract.

than that of its subcontractors ... [yet] not so culpable as to render it liable for breach ..." 155 N.E.2d at 441 .

Fuller \& Perdue, supra note 4 , pt. 2, at 381 , suggest that the decision to discharge hinges on "a covert influence of the desire to reimburse detrimental reliance." The Allbr case deals with the problem more directly.

55. See, c.g., Young v. City of Chicopee, 186 Mass. 518, 72 N.E. 63 (1904).

56. Untform Sales Act $\S \S 7,8,22$. Compare Uniform Comsuerctal Code $\S \S 2-509$, 2-510; Uniform Vendor \& PURchaser Risk ACT \& 1.

57. The Sales Act, stating that risk follows title, may prevent courts from compensating sellers for expenses incurred manufacturing or purchasing property in reliance on a contract, and may allow the seller to recover these expenses only when title has passcd, UNIForar SALES ACT $\S 63$, or when the buyer has in some way benefited from the property before title passes, $c f$. Kirtley v. Perham, 176 Cal. 333, 168 Pac. 351 (1917); Wilson v. Clark, 60 N.H. 352 (1880). Furthermore, statutes such as the Sales Act and the other acts cited in note 56 supra, by placing risk only on one person at a time, prevent courts from splitting loss. 
On the other hand, the event which triggers discharge is often destruction of property which was not and could not have been obtained in reliance-for example, a house which is the subject of a contract of repair. In awarding compensation to the repairman for the reasonable value of his partial performance, American courts never explicitly consider the loss suffered by the owner from the destruction of his home. But if the destruction resulted from a disaster against which it is not the custom of the community to insure, the owner may have suffered a loss so great that he will be unable to bear any of the repairman's reliance loss. In such a situation, therefore, a court using a mechanical rule of recovery may place the entire loss on the one of two inuocent parties who is less able to bear it. No one could reasonably suggest that the repairman be required to compensate the owner, in whole or in part, for the latter's property loss. But a consideration of that loss might be relevant as to whether or to what extent the owner ought to compensate the repairman. To balance the owner's destruction loss against the repairman's reliance loss is not so novel a suggestion as it might seem. Under existing law, a court need not attenuate the concept of benefit to award recovery for partial performance. Instead, it might apply the strict restitutionary rule of recovery, find no benefit to the home owner, and place the entire reliance loss on the repairman. ${ }^{35} \mathrm{This}$ is not to say that the destruction of the owner's house is the only factor that the court should consider; it is, however, one that should not be ignored in any attempt to achieve equitable distribution of loss.

After a court has discharged full performance under a contract and has decided how much and what kind of loss a party is to be compensated for, it must translate its decision into a sum of money. The formulae employed for determining this sum vary among American courts, ranging from a pro rata portion of the contract price to the value conferred upon the person receiving the performance when lower than such a pro rata share..$^{30}$ Different formulae produce different results. The selection of the particular formula to apply in a given case should depend therefore upon the extent to which it achieves an equitable disposition. A party receiving a pro rata share of the contract price (including the profits attributable to the work he has done) may receive at least part of the advantage he expected to derive from the contract. Nothing objectionable exists in this if partial performance could have been rejected, but was instead voluntarily accepted. ${ }^{60}$ By voluntary acceptance, the party receiving

58. See Carroll v. Bowersock, 100 Kan. 270, 164 Pac. 143 (1917).

59. American courts generally agree on a ceiling of a pro rata portion of the contract price. E.g., In re Lake's Estate, 123 N.Y.S.2d 307 (Surr. Ct. 1953); M. Ahern Co. v. John Bowen Co., 334 Mass. 36, 133 N.E.2d 484 (1956); Stein v. Shaw, 6 N.J. 525, 79 A.2d 310 (1951) ; Sergent v. McLeod, 209 N.Y. 360, 103 N.E. 164 (1913); see RestateMIENT, CONTRACTS \& 468 (3) (1932).

60. See Ontario Deciduous Fruit-Growers' Ass'n v. Cutting Fruit Packing Co., 134 Cal. 21, 66 Pac. 28 (1901); cf. Tanner v. Childers, 108 Utah 455, 465-66, 160 P.2d 965, 970 (1945) ; Snipes Mountain Co. v. Benz Bros., 162 Wash. 334, 298 Pac. 714 (1931). For the view that buyer has no right to reject partial delivery when full performance is impossible, see Seidenberg v. Tautfest, 155 Ore. 420, 424-25, 64 P.2d 534, 536 (1937) (dictum). 
partial performance may be said to have indicated a willingness to pay a pro rata portion of the contract price and thus in effect entered a new contract which is not discharged. ${ }^{61}$ When, however, the party receiving performance had no opportunity to reject it, less reason exists to compensate the performer for part of his expectation. Since the receiving party bargained for full and may not have desired partial performance, he should be charged only the value of that which was actually conferred upon him, ${ }^{62}$ normally the market price of the product or the result of the performance rendered.63 Occasionally, the results or products of the performance received may be of no value in and of themselves, as when a room has been stripped bare of fixtures in the course of redecorating. In such a case it is not the result of the performance which should be valued but the performance itself, to the extent that it promoted the ends to be achieved by the contract. ${ }^{64}$ When a party must pay for performance or expenses which did not benefit him at all, different considerations ate applicable. Since the receiving party did not gain by virtue of such expenses, the performing party should be compensated, at most, for his out-of-pocket loss. ${ }^{65}$ American courts do not always make these distinctions in selecting an applicable formula. In alteration cases, for example, some courts allow a repairman working on a house to recover a pro rata portion of his profits, as well as his costs, although the performance rendered was clearly of no value to the home owner: ${ }^{6 B}$ Because the courts do not generally distinguish

61. Cf. 2 Witliston, Sales $\S 460$ (rev. ed. 1948).

62. Cf. Uniform Sales ACT $\$ 44(1)$. This provision is not aimed particularly at burdensome contracts, but the philosophy it evidences applies equally well to cascs of breach and no breach.

63. The cases generally do not explioitly mention "market price" as the standard for valuation. They instead speak in terms of "reasonable value." But market valuc, the amount third persons would pay for the performance, seems the test actually applied. See Rothkopf v. Lowry \& Co., 148 F.2d 517, 520 (2d Cir. 1945) ; Eastern Expanded Metal Co. v. Webb Granite \& Constr. Co., 195 Mass. 356, 81 N.E. 251 (1907) ; Stein v. Shaw, 6 N.J. 525, 79 A.2d 310 (1951); Wolfe v. Howes, 20 N.Y. 197, 203 (1859) ; Landa v. Shook, 87 Tex. 608, 30 S.W. 536, aff'd on retrial, 31 S.W. 57 (Tex. Civ. Ct. App. 1895); 6 Corbin, Contracts $\$ 1370$ (1951); of. Winch v. Warner, 186 App. Div. 710, 714, 174 N.Y. Supp. 819, 823 (1919). In cases where an attorney's death causes discharge beforc completion of performance it is sometimes difficult to tell whether the court is compensating the attorney's estate for the value to the attorney of the work he has done or the value of benefit the client receives from this work. See In re Levy's Will, 207 App. Div. 183, 18894, 201 N.Y. Supp. 818, 822-26 (1923), where both tests were simultancously applied.

64. See Buccini v. Paterno Constr. Co., 253 N.Y. 256, 170 N.E. 910 (1930) ; ReststT:MENT, Contracts $\S 468$, comment 3, illustrations 2, 3 (1932).

65. This is what courts must be doing when they compensate for "value" of services (limited by a pro rata portion of the contract price) when no benefit is present. Sec Keeling v. Schastey \& Vollmer, 18 Cal. App. 764,124 Pac. 445 (Dist. Ct. App. 1912) ; Moore v. Robinson, 92 IIl. 491 (1879) ; Young v. City of Chicopee, 186 Mass. 518, 72 N.E. 63 (1904) ; Angus v. Scully, 176 Mass. 357, 57 N.E. 674 (1900); Acme Plumbing \& Henting Co. v. Hirsch, 121 Neb. 134, 236 N.W. 137 (1931); Wolf v. Altmeyer, 8 Pa. Dist. 408 (C.P. 1899).

66. Hayes v. Gross, 9 App. Div. 12, 17, 40 N.Y. Supp. 1098, 1102 (1896), aff'd on opinion below, 162 N.Y. 610,57 N.E. 1112 (1900); accord, Tripp v. Henderson, $158 \mathrm{Fla}$. 
between situations in which benefit is and is not present, formulae for recovery are frequently applied to reach irrational results. ${ }^{67}$

\section{The Englise Approach}

In 1943, Parliament passed the Law Reform (Frustrated Contracts) Act, ${ }^{\text {cs }}$ designed to permit limited apportionment of losses suffered by parties to certain discharged contracts. Prior to the celebrated case of Fibrosa Spolka Akcyjna v. Fairbairn Lawson Combe Barbour, Ltd., ${ }^{60}$ English courts allowed losses to lie where they fell at the time of discharge on the theory that "it is really impossible in such cases to work out with any certainty what the rights of the parties in the event which has happened should be."70 Thus, sums payable after the discharging event ceased to be payable; ${ }^{\pi 1}$ but sums paid were retained, ${ }^{72}$ and unpaid sums payable prior to the discharging event were recoverable. $^{73}$ In Fibrosa, the House of Lords reversed its longstanding rule and allowed a purchaser to recover a prepayment from his vendor. ${ }^{74}$ But the

442, 444, 28 So. 2d 857, 858 (1947); Anderson \& Son v. Shattuck, 76 N.H. 240, 244, 81 At1. 781 (1911) ; Weis v. Devlin, 67 Tex. 507, 3 S.IW. 726 (18S7); Halsey v. Waulesha Springs Sanitarium, 125 Wis. 311, 314, 104 N.W. 94, 95 (1905) ; cf. Haas v. D'Avanzo, 45 So. 2d 104 (La. Ct. App. 1950).

67. In addition to cases cited note 66 infra, see Whelan v. Ansonia Clock Co., 97 N.Y. 293 (1884), where plaintiff agreed to varnish clock cases for defendant in defendant's factory. Plaintiff was to be paid only when the cases were inspected and approved by defendant's agent. Defendant's factory was burned, destroying many of the cases, some completely, others partially finished, none of which had been inspected. Plaintiff recovered the contract price for the finished cases and quantum meruit for the unfinished ones. Assuming that plaintiff made a profitable deal, at least for the completed cases, plaintiff was compensated not only for his out-of-pocket costs but for part of his expectation. It is bad enough to shift the complete reliance loss to defendant who lost his factory; to measure this reliance loss so as to include profits is to stretch out of proportion the existing inequities of the "all-or-nothing" approach.

68. 6 \& 7 Geo. 6, c. 40 (1943). See generally Wurianss, Law Reroras (Frustraten Coniracts) Act, 1943 (1944); McNair, The Law Reform (Fristratcd Controcts) Act, 1943, 60 L.Q. Rev. 160 (1944); Williams, Statutes, 7 Mod. L. Rev. 66 (1944); Comment, 46 MícH. L. Rev. 401, 420-21 (1948); Note (pts. 1 \& 2), 93 L.J. 315, 326 (1943); Notc, 10 SoL. 141 (1943).

69. [1943] A.C. 32 .

70. Chandler v. Webster, [1904] 1 K.B. 493, 499 (C.A.) (Collins, MI.R.).

71. E.g., Kreil v. Henry, [1903] 2 K.B. 740 (C.A.).

72. Chandler v. Webster, [1904] 1 K.B. 493 (C.A.); Civil Serv. Coop. Soc'y v. General Steam Nav. Co., [1903] 2 K.B. 756 (C.A.) ; Anglo-Egyptian Nav. Co. v. Rennnie, L.R. 10 C.P. 271 (1875). Chandler v. Webster was the first case in which it was held that a promisee could not recover his down payment in situations where consideration totally failed. In former cases in which down payments were nonrecoverable, the promisors had partially performed although the promisees were not benefited. See Wrunass, Law Rerosss (Frustrated Contracts) ACT, 1943, at 10-17 (1944).

73. Chandler v. Webster, [1904] 1 K.B. 493 (C.A.).

74. In Fibrosa defendant in England agreed to manufacture and deliver two fax hackling machines to plaintiff in Poland. Plaintiff made a down payment of $£ 1000$ and 
vendor was not permitted to recover or set off against the prepayment the value of his nonrecoverable essential reliance expenditures. Furthermore, $\mathrm{Fi}$ i rosa did not clearly reverse the rule that a party could not be compensated on discharge for partial performance other than prepayment. ${ }^{75}$ Although several of the Lords recognized that the rule of Fibrosa could not "be regarded a. dealing fairly between the parties in all cases," "they believed that any further provision for placing or apportioning loss was a function of the legislature.77 In response, Parliament passed the Law Reform (Frustrated Contracts) Act. which provides:

$\S 1$ (2). All sums paid or payable to any party in pursuance of the contract before the time when the parties were so discharged . . . shall, in the case of sums so paid, be recoverable from him ... and, in the case of sums so payable, cease to be so payable:

Provided that, if the party to whom the sums were so paid or payable incurred expenses before the time of discharge in, or for the purpose of, the performance of the contract, the court may, if it consiclers it just to do so having regard to all the circumstances of the case, allow him to retain or, as the case may be, recover the whole or any part of the stums so paid or payable, not being an amount in excess of the expenses so incurred.

$\S 1(3)$. Where any party to the contract has, by reason of anything done by any party thereto in, or for the purpose of, the performance of the contract obtained a valuable benefit (other than the payment of money to which the last foregoing subsection [ $\$ 1(2)$ quoted above] applies) before the time of discharge, there shall be recoverable from him by the said other party such sum (if any), not exceeding the value of the saicl benefit to the party obtaining it, a's the court considers just, having regard to all the circumstances of the case and, in particular,-

(a) the amount of any expenses incurred before the time of discharge by the benefited party in, or for the purpose of, the performance of the contract, including any sums paid or payable by him to any other party in pursuance of the contract and retained or recoverable by that party under the last foregoing subsection, and

(b) the effect, in relation to the said benefit, of the circumstances giving rise to the frustration of the contract. ${ }^{78}$

defendant partially manufactured the machines when Germany's invasion of Poland pre. vented delivery and the contract was discharged. Defendant's losses may have been recoverable in Fibrosa, see [1943] A.C. at 76, but the discussion in text, like mtich of the discussion in the opinions, see $i d$. at $49,50,54,78$, assumes the nonrecoverability of seller's reliance expenditures.

75. See Appleby v. Myers, L.R. 2 C.P. 651 (1867); Writaus, op. cit. supra note 72, at $2-7$.

76. [1943] A.C. at 49.

77. Id. at 49-50 (Viscount Simon), 54 (Lord Atkin), 63, 72 (Lord Wright), 78 (Lord Porter).

78. Law Reform (Frustrated Contracts) Act, 1943, 6 \& 7 GEo. 6, c. 4Q §§ 1(2)-(3). There have, as yet, been no reported cases under either of these subsections of the act. Thic act was enacted in Victoria, Australia in 1959 with some slight modifications. Scc Donovan, Law Reform in Victoria, 1960 J. Bus. L. 62, 64-65. 
Subsections 1(2) and 1(3) allow the setoff of essential reliance expenses against the restitution of benefits received to the extent that the court deems just. Subsection 1(2), apart from the proviso, enacts into statutory form the rule of the Fibrosa case by providing for restitution of money paid or payable prior to the discharging event. The proviso, however, goes beyond codification of Fibrosa to provide for the setoff of expenses incurred in partial performance against sums paid or payable. Subsection 1(3) extends the restitutionary recovery and setoff of essential reliance expenditures to cases in which the partial performance of one party, other than the payment of money, confers a benefit upon the other. These subsections are operationally interrelated, so that, a party benefited may have to pay under both subsections. Assume $A$ contracts to build a house for $B$ for 5,000 pounds, 1,000 down and 4,000 upon completion, $B$ to supply part of the materials used. TVthen the house is two-thirds built, a National Defense Regulation prohibits all private building for the duration of the emergency. If $B$ were to sue $A$ under subsection (2) for recovery of the downpayment, $A$ could set off his essential reliance expenses against the 1,000 pounds and could counterclaim under subsection (3) for the value of benefit conferred upon $B$ in excess of the expenses set off by $A$ under subsection (2). $B$ could set off against the value of the benefit received in excess of $A$ 's subsection (2) deduction the value of his reliance expenditures for materials. ${ }^{79}$

Although provision for the shifting of certain essential reliance losses effects a change in English law, this alone is not a significant contribution to the problem of loss distribution following discharge. As pointed out above, no particular virtue inheres in the mechanical shifting of loss from one party to another. The act's contribution lies rather in the fact that it can be interpreted to give a court discretion to apportion, rather than simply shift, loss between the parties. ${ }^{\text {so }}$ A party who has made or agreed to make prepayments may, for example, recover or retain only such sum as the court considers just in the light of the essential reliance expenses the other party incurred and other circumstances of the case. This fact, together with the provision that the paying party may recover or retain "the whole or any part" of what he has paid or is payable not "in excess of the expenses so incurred," seems to indicate that less than the full essential reliance expenses may be set off against the sum paid or payable in advance. If this is so, subsection 1(2) contemplates a split of the reliance loss in relation to the equities of the case. Similarly, the discretionary language of subsection $1(3)$, which permits a court to grant restitution for the value of partial performance "as ... [it] considers just, having regard to all the circumstances of the case and in particular . . . any expenses incurred . . . by the benefited party," is susceptible of a loss-sharing interpretation. On the other hand, both subsections can be read to restrict the court to (1) ignoring the reliance expenses of the pay'ee or benefited party

79. See McNair, supra note 68 , at $166-67$.

80. See WiLLIAXrs, op. cit. stipra note 72, at 35-37. 
or (2) allowing a set off for all such expenses up to a maximum of the sums paid or payable under subsection $1(2)$ or the value of the benefit conferred under subsection 1(3). The act nowhere expressly provides for the division of loss resulting from essential reliance expenses. Furthermore, parliamentary history indicates that this second reading was the one intended by the drafters of the act, at least for subsection 1(2), on the theory that a stipulation for prepayment is a contractual provision for loss allocation. ${ }^{81}$ It is unlikely, however, that parliamentary history will be admissible for the purposes of construing the act. ${ }^{82}$ English courts, faced in the future with the problem of dealing equitably with discharge cases, may therefore interpret the language of the act to permit court-imposed sharing of reliance loss.

Assuming that the act will be so interpreted, the effectiveness of apportionment will depend largely on when and what kind of reliance loss can be considered by the court. The salient weakness of the act is that reliance loss is taken into consideration only as set off against the return of prepayments ${ }^{8:}$ or the value of other benefiting performance. If a party has not received or stipulated for payment in advance and has not conferred a benefit, his reliance expenditures are not recoverable. Why compensation for a reliance loss should depend upon the fortuitous circumstances of receipt or payment or partial performance is unclear. Payment in advance seems relevant only when it is intended as a contractual provision for loss allocation. But parties rarely anticipate the occurrence of a discharging event, and if they did and intended the prepayment provision to provide for the incidence of loss, the entire prepayment should be retainable with no return of the excess over the expenses incurred. Indeed, subsection $2(3)$ of the act so provides. ${ }^{84}$ As the act is presently worded, irrational results may obtain; a promisor, for example, who agrees to or makes a payment in advance may have to pay for all or part of the promisee's essential reliance expenses, but if no prepayment is made or provided for, the same promisor in the same situation will bear none of the promisee's reliance loss.

In addition to the setoff provisions of the act other limitations are imposed upon the kinds of losses with which a court may deal. These limitations may be illustrated by a hypothetical case. $A$ agreed to deliver widgets to $B$ as $B$ requires them. The sale of widgets was subsequently cleclared illegal and the contract discharged. A stock of widgets already manufactured by $A$ when the contract was made worth 1,000 pounds was to constitute the first shipment for which $B$ bargained. $A$ voluntarily spent 1,000 pounds advertising the wid-

81. See Law Revision Committee, Report, CMo. No. 6009, at 7 (1939); 128 H.L. Dex. (5th ser.) 136,138 (1943); WiLlanss, óp. cit. supra note 72, at 37-38.

82. See Transport \& Gen. Credit Corp. v. Morgan, [1939] 1 Ch. 531, 551-52; Assam Rys. \& Trading Co. v. I.R. Comm'rs, [1935] A.C. 445, 457-59; Ellerman Lines, Ltd. v. Murray, [1931] A.C. 126, 147; WilliaMs, op. cit. supra note 72, at $37 \mathrm{n} 32$.

83. See $i d$. at 9.

84. This section provides that the provisions of the act are subject to contrary contractual provisions. See id. at 59-62. 
gets in $B$ 's area. $B$ made a 1,000 pound downpayment and, pursuant to agreement, spent 500 pounds (an expense considered in the sales price) remodeling his showroom properly to display the widgets for resale. In order for $A$ to set off any of his expenses against $B$ 's downpayment, these expenses must have been made "in, or for purpose of, the performance" of the contract. Since $A$ made the widgets before he entered into the contract with $B$, it cannot be said that the cost of the widgets was expended "in performance." Whether the cost of the widgets falls under the "for the purpose of . . . performance" category" depends upon whether "for the purpose of the performance," is given a narrow or broad interpretation. Read narrowly, this phrase refers to the costs of manufacture or purchase of the widgets in reliance on the existing contract as opposed to the costs of delivery which would be an expense "in ... performance" of the contract. Read broadly, "for the purpose of the performance" would include "not only preparation for performing . . . after the contract has been entered into, but also preparation for the contract before the contract has been entered into." 85 The manufacture or purchase costs of the widgets $A$ had on hand would fall within this broad interpretation. But since the phrase "for the purpose of the performance" also appears in subsection 1(3) where it is envisioned that such expenses will benefit another party, the narrow reading was probably intended; acts done in preparation for a possible future contract would not ordinarily, without more, accrue to the benefit of a party to such a contract. In addition, a broad reading strains the words of the act. The only conclusion that can be reached as to the cost of the widgets is that it might, but is unlikely to be, considered as an "expense" under the act. ${ }^{80}$ Since no contractual provision existed requiring $A$ to advertise the widgets, the cost thereof (an incidental reliance expense) would probably not be regarded as an expense made "in, or for the purpose of, the performance." Emphasis on performance appears to eliminate from consideration such incidental reliance expenses unless they are subsumed by the "all the circumstances" terminology. $B$ 's 500 pound expense for remodeling the show room was an essential reliance expense. But $A$ bestowed no benefit on $B$, and $B$ therefore has nothing against which to set off the remodeling expense. These expenses can be recovered, therefore, only if they benefited $A$, as provided in section 1(3). "Benefit" is not defined in the statute, and, as in American cases, it probably can be defined narrowly or broadly, depending on the court's view of the equities. But even under an attenunted definition of benefit, it is difficult to see how $A$ could gain from the remodeling until some widgets were actually placed in the showroom for display. Thus, it is probable that the only recovery in this case would be restitution of the downpayment to $B$. $A$ loses 2,000 pounds-1,000 for the manufacturing cost of the widgets and 1,000 for advertising expenses-and $B$ loses 500 pounds-the cost of remodeling his showroom. Only if the mandate that the court is to "regard

85. Id. at 43.

86. See id. at 44. 
... all . . . circumstances of the case" is read very broadly will the court be able to consider all the expenses essential to an equitable apportionment of loss.

\section{A New Approach}

Neither the English nor the American approach to the disposition of losses resulting from a contract discharged as burdensome is responsive to the equities of the average discharge case. The scope of the losses which the courts expressly consider and their powers to deal with these losses are unnecessarily limited. The circumstances of different cases naturally incline toward different distributions of loss. Courts discharging burdensome contracts, therefore, should be given maximum flexibility to deal with the great variety of fact situations which may confront them. Several general principles, gutidelines for decision, emerge from study of the inadequacies of decided clischarge cases. First, any new approach should not abrogate the traditional rule of restitution. To the extent that $A$ 's loss has actually benefited $B, B$ should make restitution to $A$. In a great many cases, restitution is the only remedy that need be applied in order to attain a fair result. ${ }^{87}$ Contemporary courts only have trouble with restitution when they try to make it cover situations which do not fit within its framework-where $A$ 's loss does not in any realistic sense benefit $B$. Second, since both parties are ordinarily faultless and equally relieved of their contractual rights and duties, it seems most equitable to place reliance loss equally on both of them..$^{88}$ Third, although the rationale of loss splitting is the avoidance of overburdening one of two innocent parties, situntions exist in which an even split of loss will be inequitable. This will happen, for example, where a buyer incurs unusually high incidental reliance losses. To make the seller share the buyer's loss might be to force the seller to spend much more than he would have spent had the contract not been discharged and perhaps more than he can reasonably afford. It is in cases like this that the necessity of a limit becomes evident. The limit of court-imposed loss should be the maximum a party could have lost had the circumstances occasioning discharge not arisen. This will equal the essential and incidental reliance losses already incurred plus essential and incidental reliance expenses which would have been incurred. Fourth, courts should be able to adjust contractual obligations in appropriate situations. If the total loss can be reduced by changing the duties of the parties, then this should be clone. Finally, courts should be able expressly to consider all the circumstances of the case, including which party, because of a disaster occasioning discharge, has suffered the greatest loss. One of the most obvious equities is the loss resulting from property destruction. When this loss cannot be or is not customarily insured against, the court should be free to weigh it along with other factors in the case to achieve a just balance of total loss.

87. See notes 34-35 supra and accompanying text.

88. See notes $29-30$ supra and accompanying text. 
It is unlikely that American courts will adopt a satisfactory loss-apportionment system without the aid of a statute. If courts have the power to abrogate the terms of a contract and declare it discharged, it would seem that they have the power to apportion resulting loss not already placed by statute. ${ }^{80}$ Indeed, they have apportioned in a hit-or-miss fashion by manipulation of the restitutionary rule.90 But courts which have acknowledged the inadequacies of traditional approaches to loss disposition have also noted that the common law does not permit them forthrightly to divide loss between the parties to a discharged contract. The words of Viscount Simon's opinion in Fibrosa are equally applicable to the American judiciary's perception of its limitations in discharge cases: ":A restitutionary recovery alone] can not be regarded as dealing fairly between the parties in all cases, and must sometimes have the result of leaving [one party] ... at a grave disadvantage. . . . These results follow from the fact that the ... common law does not undertake to apportion [loss] .... It must be for the legislature to decide whether provision should be made for an equitable apportionment . . ."92 Thus a statute is needed. Such a statute must give the judiciary broad discretion to deal with discharge cases on equitable grounds, yet it should emphasize those factors relevant to the equitable distribution of loss which courts seem to have overlooked. A statute designed to meet these requirements is set forth below with accompanying comments explaining the mechanics and rationale of its provisions.

\section{Section 1. Applicability}

This act is to be applicable when pcrformance of a contract becomes so burdensome that a court discharges all parties from their contractual obligations.

\section{COMMENT}

This act does not prescribe the conditions under which a court may discharge full performance of a contract as burdensome. The most common doctrinal grounds for such a discharge are "impossibility of performance" or "frustration of purpose." The act is framed broadly, however, so that it will be applicable whenever a court utilizes any doctrine to excuse contractual

89. Except for statutes placing loss from destruction of property, e.g., UNifoses SALES ACT $\S 22$, and repeating the restitutionary rule, e.g., CAL. Crv. Code Axx. § 1514, no American statutes dealing with loss from burdensome contracts have been found.

90. See note 55 supra and accompanying text.

91. "The expense which plaintiff has sustained up to ... [discliarge] was a loss which the trial court was unwilling to visit upon either party, neither being at fault, and consequently it divided the expense between them. We find no rule which authorizes that disposition of the matter." Binz v. National Supply Co., 105 S.W. 543, 545 (Tex. Ct. Civ. App. 1907).

92. Fibrosa Spolka Akcyjna v. Fairbairn Lawson Combe Barbour, Ltd, [1943] A.C. $32,49$. 
obligations. ${ }^{93}$ Parties may contract out from under the provisions of this act; any party may contractually assume the risk so that the contract will not be discharged. ${ }^{94}$ Similarly, parties may contractually provide for the use of a particular loss allocation formula or for arbitration of the question of who is to bear the loss; in either case, the operative provisions of this act will not apply (see preamble to section 8 ). One of the aims of this act is to bring the problem of loss resulting from discharged contracts to the attention of contracting parties so that they may provide for loss allocation.

\section{Section 2. Purposes}

The purposes of this act are: (a) to enable a court equitably to apportion loss among the parties to a contract discharged within the meaning of this act; and (b) to enable a court to adjust contractual obligations so as to minimize loss suffered by parties to a contract discharged renthin the meaning of this act.

\section{COMMENT}

Section 2 is the most significant provision of this act. The weaknesses of existing law would be sufficiently remedied if the courts were granted the power, without more, to minimize and apportion loss resulting from a discharged contract. The remaining provisions of this act are designed to facilitate fitlfillment of these purposes in the following manner. The court will first order any party who has received benefit (as defined in section 3(a)) from another party's performance to compensate that second party for the value of the benefit, according to section 7 . The total apportionable loss, not including that subject to compensation under section 7 , will then be calculated under section 5 . The court may then modify the provisions of the contract in order to reduce total apportionable loss and apportion the reduced loss as it deems just (section $8(a))$. In cases where the court is unable or finds it infeasible to reduce loss by modification, it will ordinarily apportion loss, not including that subject to compensation under section 7 , evenly among the contracting parties as provided in section $8(\mathrm{~b})$. But the court may disregard this formula for apportionment in any case where it will produce inequitable results, and insteat apportion losses in any manner the court deems just (subsection 8(c)) except that no party shall suffer a loss after apportionment greater than his loss actually incurred plus his predicted reliance expenses (defined in subsection $3(\mathrm{f})$ and explained in the comment to section 8 ) and no party shall be forced to

93. German courts in the 1920 's, for example, initiated the utilization of Oertmann's doctrine of Geschäftgrindlage to deal with the disastrous economic situation of the time. See note 19 supra. American courts have not been as prone to disturb contractual relationships as those of Germany. But "our common law is still flexible and capable of growth, and ... there is sufficient support for the decision of new cases in accordance with the justice of the time." 6 Corbin, Contracts $\S 1360$, at 402 (1951).

94. See note 24 supra and accompanying text. 
pay another for loss attributable to the destruction of nonintegral property (defined in section 3(e) and explained in the accompanying comment).

\section{Section 3. Definitions}

(a) Benefit. For the purposes of this act, a party to a contract is benefited when another party's reliance expenses confer on the first parly an actual gain of pecuniary value to the first party which is not destroyed by the cent occasioning discharge of the contract.

(b) Essential reliance expenses. Expenses a party incurs fulfilling his promised performance under the terms of the contract.

(c) Incidental reliance expenses. All expenses incurred in reliance on a contract except essential reliance expenses.

(d) Integral property. Property is integral to a contract when it atas constructed, manufactured, made, bought, raised, or grown in reliance solely on the contract; or when it would have been constructed, mannfactured, made. bought, raised, or grown in reliance solely an the contract had a party not already had it in his possession in a condition uscful for the contract's purposes when the parties entered into the contract.

(e) Nonintegral property. All property except integral properiy.

(f) Predicted reliance expenses. Reliance expenses, not actually incurred, which the court finds a party would have incurred had the circumstances occasioning discharge not arisen.

(g) Reliance expenses (or "expenses made in reliance"). Expenditures of money, services, property, or anything else of pecuniary value made in reliance on the contract, except the expenditure of properly constructed, mannfactured, nade, bought, raised, or grown in reliance on the contract.

\section{COMMENT}

(a) Benefit. The definition of benefit is essential to the operation of section 7 of this act, which provides a restitutionary recovery for a party whose performance "benefits" another party to the contract. Benefit is defined narrowly to mean a gain of pecuniary value to the recipient which is not destroyed by the event occasioning discharge. A party's performance thus may result in losses recoverable under section 7 if (1) it has conferred upon another party to the contract money or something worth money in the sense that third persons would be willing to pay for it (indicated by the statutory words "actual gain of pecuniary value"), or (2) it has promoted the ends to be achieved by the contract (indicated by the statutory words "pecuniary value to the first party"). It should be emphasized that benefit is defined in this section requires gain to the receiving party, and therefore something more than simply performance of that for which a promisee bargained and was willing to pay a price prior to the event which occasioned discharge.

This act's definition of benefit precludes the common judicial practice of attenuating the concept of benefit in order to allow recovery for losses which 
have not actually resulted in gain to another..$^{05}$ It will be unnecessary for a court applying this statute to manipulate the concept of benefit in response to the underlying equities of a particular case; losses not compensated under the strict restitutionary rule of section 7 are covered by the apportionment provisions of section 8 . The statutory method for evaluating benefit is prescribed in section 4. Examples illustrating the operation of restitutionary recovery under this act are set forth in the comment to section 7 .

(b) Essential reliance expenses. ${ }^{90}$ This term refers not only to expenses incurred in performance of acts promised under the terms of the contract, but also expenses necessarily incurred before the promised acts can be performed. Thus, if $A$ agrees to sell and deliver widgets to $B, A$ 's essential reliance expenses include not only the cost of delivery but the cost of buying or manufacturing the widgets. But the term "essential reliance expense" does not include expenses incurred before a contract is made. If $A$ in the above example had the widgets in existing stock before he agreed to sell them to $B$, the cost of buying or manufacturing the widgets would not be an essential reliance expense. This would be so even if $A$ bought or manufactured the widgets in preparation for a possible future contract with $B$.

(c) Incidental reliance expenses. ${ }^{97}$ This term refers to expenses incurred in expectation that another party will fully perform under a contract. It includes all expenses incurred in reliance on a contract which are not classified under this act as essential reliance expenses. A party does not have a contractual obligation to incur incidental reliance expenses; nor are they necessary for the proper performance of contractual obligations. If $A$ agrees to sell widgets to $B$ and $B$ in anticipation of full performance advertises them for resale, the advertising costs are incidental reliance expenses. Like essential reliance expenses, incidental reliance expenses include only expenses incurred in reliance on the contract after its formation.

(d) Integral property. The term "integral" is adopted to designate the kinds of property which if destroyed, may result in losses apportionable among the parties to the contract. Most apportionable losses will result from nonrecoverable reliance expenses; and integral property loss will ordinarily be an essential reliance loss. If, for example, $A$ agrees to manufacture and sell radios to $B$ and prior to delivery $A$ 's factory, including all completed radios. is destroyed, the manufacturing cost of the destroyed radios is an integral property loss which is also an essential reliance loss. If, however, $A$ in the above example had the radios in existing stock before he made the contract of sale with $B$, the manufacturing cost of the radios would not be an essential reliance loss, but would be an integral property loss. Losses resulting from

95. See note 39 sipra and accompanying text.

96. The term "essential reliance" is taken from Fuller \& Perdue, The Reliance Interest in Contract Damages, pt. I, 46 Yale L.J. 52, 78 (1936).

97. "Incidental reliance" is also taken from Fuller \& Perdue, supra note 96, pt. 1, at 78. Note, however, that this statute refers only to reliance "expenses" and not the entire "reliance interest" as do Fuller and Perdue. See note 8 sipra. 
the destruction of integral property are apportionable under this act in the same manner as essential reliance losses on the theory that a party's right to recovery ought not ordinarily to depend on the time of formation of the contract. Excluded from integral property is property destroyed or rendered useless prior to the formation of the contract, even though the parties' lack of knowledge of a previous disaster may be a substantive ground for discharge, ${ }^{95}$ on the theory that losses of property the existence or usefulness of which is erroneously assumed by both parties at the formation of the contract generally should be borne by the party who would have sustained it had no contract been entered, since losses which are realizcd before the formation of the contract should not be shared.

(e) Nonintegral property. This term refers to the kinds of property which, if destroyed, will not result in losses apportionable among the parties to a contract under the provisions of this act. The term includes, for example. property not connected with any party's performance under the terms of the contract, and property which is the subject of the contract but which had already been destroyed or rendered useless when the contract was entered. Under certain circumstances (set forth in section 5 and the comment thereto), however, the loss resulting from the destruction of nonintegral property will affect the extent to which the property owner must share apportionable loss resulting from the contract.

(f) Predicted reliance expenses. The meaning and function of "predicted reliance expenses" are explained in the comment to section 8.

(g) Reliance expenses. This term is defined broadly and is intended to cover anything done in reliance on the contract translatable into pecuniary value. Thus, if a carpenter contracts to build cabinets, his reliance expenses may include not only such direct expenses as the value of materials used, the salary of helpers, and the value of his time and efforts attributable to performance of the contract, but such indirect expenses as the value of overhead expenses allocable to the contract. The expenditure of materials in the above example is a reliance expense under this act only if the materials were not acquired in reliance on the contract. Otherwise, there would be a reliance expense at the time the carpenter bought the materials and another at the time he expended them. Since reliance expenses may be included in apportionable loss under section 5 , the exception to subsection $3(\mathrm{~g})$ is designed to prevent double recovery.

\section{Section 4. Valuation}

(a) Benefit shall be valued at a pro rata portion of the contract price if the recipient of benefit had an opportunity to decline it. Otherwise, benefit shall be valued at its market price at the time it was reccized or a pro rafa portion of the contract price, whichever is lower; or if there is no determinable market price, benefit shall be valued at the contract price less the amount a subsequent

98. See note 24 supra. 
contractor would charge to complete the ends to be achieved by the contract or a pro rata portion of the contract price, whichever is lowcr.

(b) Subject the provisions of section $8(c)$, a reliance expense actually' incurred is to be valued at its market value at the time it was incurred, and a predicted reliance expense is to be valued at its market value at the timc it would have been incurred.

(c) Subject to the provisions of section $8(c)$, integral property loss shall be valued at the original cost of the property to the party who suffercd the loss less depreciation.

(d) Subject to the provisions of section $8(c)$, nonintegral property loss shall be valued at the market value at the time it was destroyed or rendercd useless.

\section{COMMENT}

(a) Benefit. Subsection (a) prescribes the method of valuation to be used in order to calculate the amount of a restitutionary recovery under section 7 . The market price limitation is based on the premise that since the recipient of the benefit bargained for full, and may not have desired partial, performance, he should not have to pay the performing party part of the latter's expected profits under the contract. The "market price" of cash, of course, equals the cash itself. The alternative limitation of a pro rata portion of the contract price is based on the premises that the performing party ought not to be placed in a better position than he would have been in had the contract not been discharged, and conversely, that the benefited party who was not responsible for the other's failure to complete performance should not have to pay more than he agreed to pay. These limitations operate in the following manner. Assume that $A$ agrees, during a war, to build a house for $B$, contract price 20,000 dollars. When $A$ has built three-quarters of the house, Congress prohilits private building for the duration, but the partially completed structure can be preserved for future work when the war is over. The value of benefit received by $B$ is equal to its market price-the amount third parties would pay $B$ in excess of the value of the land, unless this amount exceeds 15,000 dollars (three-quarters of the contract price) in which case the benefit received woukl be valued at 15,000 dollars. If the cost of performance resulting in benefit exceeds the value of the benefit as calculated under this subsection, the exces. cost enters into the calculation of loss under section 5 .

When a benefited party has an opportunity to reject, but accepts, benefit accruing from another's performance, the market price limitation on valuation is inoperative and benefit is valued at a pro rata portion of the contract price. This provision is based on the premise that, by voluntarily accepting performance the benefited party indicated his willingness to pay the contract price. and in effect entered a new contract which is not discharged. Assume that $B$ contracts to purchase one hundred chairs from $A$, delivery to be in a single lot, contract price 1,000 dollars. $A$ 's plant, including all but ten chairs stored elsewhere, is destroyed. $A$ delivers the ten remaining chairs to $B$. If $B$ accepts. 
although he had an opportunity to reject delivery, his benefit is valued at a pro rata portion of the contract price, 100 dollars.

In some situations, benefit received may not have a determinable market price. Benefit is then to be valued at the full contract price less the amount a subsequent contractor would charge to complete the contract (or a pro rata portion of the contract price, whichever is lower). Assume that $A$ contracts to decorate the home of $B$ and that the contract is discharged after $A$ has torn out all the fixtures, leaving the house an empty shell. The benefit accruing to $B$ probably has no market value. If the contract price for the complete decorating project was 1,000 dollars and after discharge, another decorator will complete the job for 700 dollars, the performance resulting in benefit has promoted the ends to be achieved under the contract to the value of 300 dollarsthe amount $B$ must pay.

(b) Reliance expenses. Subsection (b) prescribes the method for evaluating reliance expenses that are elements of apportionable loss as calculated under section 5 . Whereas subsection (a) deals with the valuation of benefit accruing to a party from another's performance, this subsection deals with the valuation of outlays parties make in reliance on the contract which do not benefit another party. The standard used is market value. If reliance expenditures are made in money, the value of the expenditures, in the absence of a currency exchange problem, is the sum of money expended. Thus if $A$ buys Blackacre (market value 20,000 dollars) for 10,000 dollars, it is the market value of the money he paid for the property-10,000 dollars-not the market value of the pruperty-20,000 dollars-which will be taken into consideration. If $A$ pays for Blackacre with other property which had an original cost of 5,000 dollars and a market value 15,000 dollars, the value of his reliance expense is 15,000 dollars, the market value of the bartered property.

(c) Integral property. Loss of integral property is apportionable under this act because of its resemblance to reliance loss. Thus, the value of integral property loss should equal the value of the loss resulting if the property had been purchased or made in reliance on the contract. If $A$, for example, paid 1,000 dollars to buy property in reliance on the contract and the property was destroyed, the reliance loss would be valued at 1,000 dollars. This subsection assures that, if $A$ bought the same property for 1,000 dollars before the contract was made, the loss would still equal 1,000 dollars even though the market or replacement value of the property is two thousand.

(d) Nonintegral property is valued at the market value at the time it was destroyed or rendered useless because this is the closest approximation of the actual loss suffered by the owner of this property.

\section{Section 5. Apportionable Loss}

(a) Subject to the limitations of subsection (b), apportionable loss shall include only:

(1) all essential and incidental reliance cxpenses; plus

(2) all losses resulting from the destruction or rendering useless of 
integral property when such property was destroyed or rondered uscless by the event which occasioned discharge of the contract, unless the cost of such property is a reliance expense included under subsection (a) (1) of this section; plus

(3) all losses resulting from the destruction or rendering useless of nonintegral property when the destruction or rendering useless of this property was the event which occasioned discharge of the contract and when it was not the custom of the community to insure this property from the force which destroyed it or rendered it useless.

(b) Even though covered by subsection (a), apportionablo loss docs 101 include:

(1) reliance expenses to the extent to which they may be applied to a subsequent contract;

(2) reliance expenses compensable under section 7 of this act;

(3) losses for which a party is compensated by insurance as provided in section 6 of this act;

(4) reliance expenses in excess of what a prudent man in the sanc position as the party incurring such expenses would have incurred in rcliance on the contract;

(5) reliance expenses in excess of a pro rata portion of the contract price when the party incurring such expenses has imprudently contracted for a price below the expenses he could reasonably have expected to incur in reliance on the contract.

\section{COMMENT}

Loss apportionment, outside the framework of restitution, is accomplished under this statute in two steps: apportionable loss is first determined uncler this section, then apportioned in accordance with the provisions of section 8 . Section 5(a)(1) includes all essential and incidental reliance expenses in apportionable loss. A court may, but need not, apportion such losses, for the provisions of section 8 are permissive rather than mandatory. Apportionable loss, therefore, is not necessarily loss which shall be apportioned in any given case. Some incidental reliance losses, for example, may be so remotely related to a contract that it would be inequitable or infeasible to apportion them.

Subsections 5 (b) (1) to (3) exclude from apportionable loss those expenses which are recoverable from another source. Section $5(b)(2)$ makes it clear that apportionable loss is that which remains after restitution has been made uncler section 7-that is, apportionable loss does not include loss of one party which benefits another. Subsection 5(b) (1) ensures that apportionable loss cloes not include expenses which a party can apply to the performance of another contract. And 5(b) (3) excludes from apportionment losses which have been compensated by insurance.

Other types of reliance expenses are excluded from the calculation of apportionable loss by subsections $5(\mathrm{~b})(4)$ and (5). Since one party's loss will 
ordinarily be shared by another under the apportionment provisions of this act (sections 8(b) and (c)), losses incurred imprudently are not included in the total loss to be apportioned. Section $5(\mathrm{~b})(4)$ disallows reliance expenses which would not have been incurred by a prudent man. This restriction can operate in two general ways: (1) it can limit the value of any single expense; thus if $A$ spends 500 dollars to purchase particular material in reliance on the contract when others in $A$ 's position would have paid 250 dollars for the same material, $A$ 's apportionable reliance loss will be 250 dollars; (2) it can limit the kinds of expenses made; thus if $A$ buys platinum nails in reliance on a contract when a prudent man would have bought steel nails, $A$ 's apportionable loss is the cost of steel nails. Section $5(\mathrm{~b})(5)$ applies when a party incurring expenses has made an imprudent bargain. In such a case, reliance expenses in excess of that part of the contract price proportionate to the amount of work done under the contract are not considered apportionable loss. Assume that $C$ contracts to build a wing on $O$ 's house for a price of 1,000 dollars when other builders in the community would have charged 4,000 dollars. When the contract is discharged, $C$ has completed half the job and has expended 2,000 dollars in labor and materials. Only 500 dollars of $C$ 's loss will be included in the total calculated under section 5 . If $C$ 's bad bargain was not the result of imprudence but of a reasonably unanticipated rise in the market, his loss will not be limited to 500 dollars. In this case, $C$ will share his misfortune with $O$, at least to the extent of the statutory limit on court-imposed loss (set forth in section 8 and discussed in the comment thereto).

Integral property loss caused by the event which occasioned discharge is treated by this act as loss resulting from reliance expenses; it is considered as a loss under section 5 and apportioned under section 8. Often the cost of such property is a reliance expense (see section 3 and comment thereto). If $C$, for example, spent 100 dollars for the lumber to build a bar into $O$ 's home, upon destruction of the house, the loss of the lumber would be an integral property loss and the cost of the lumber would be a reliance expense. Loss resulting from the destruction of the lumber would not be a reliance loss, however, if $C$ had the lumber on hand before he entered into the contract.

Section $5(\mathrm{a})(3)$ includes certain nonintegral property losses in the statutory definition of apportionable loss. This does not mean, however, that nonintegral property loss is apportionable. Inclusion of nonintegral property loss in section 5 means only that the property owner will be able to balance his nonintegral property loss against another party's reliance and/or integral property loss. The use of nonintegral property loss as a balance is limited to occasions when the property was not insured and was destroyed by a force against which it was not the custom of the community in insure. In addition, under the broad discretionary grant of section 8(c), a court may ignore nonintegral property loss as a balance when it deems it just to do so. Thus, section 5 (a) (3) gives a court apportioning loss the opportunity to acknowledge an equity often existing, but rarely considered in discharge cases-the destruction of property by the discharging disaster. 


\section{Section 6. Insurance and Insurers}

Any sum due under an insurance policy covering any of the eloments of total apportionable loss as described by section 5 shall be calculated without reference to the apportionment provisions of this act. The insurer shall not have a right to recover any portion of such sum from any party to the contract by subrogation. Such sum due under an insurance contract shall be subtracted from the total apportionable loss in accordance with section $5(b)(3)$.

\section{COMMENT}

This section is designed to ensure that any loss covered by insurance is to be borne by the insurer. ${ }^{00}$ An insurance company is denied the opportunity to share its loss by subrogating itself to the rights of the insured in accorclance with the law of many American jurisdictions which, in some situations, do not permit an insurer to be subrogated to the insured's rights against a faultless party. ${ }^{100}$ This is to be distinguished from a case such as Hall \& Long $v$. Railroad Co., ${ }^{101}$ in which the party liable to the insured is a wrongdoer, such as a tortfeasor. ${ }^{102}$,In the former situation, no reason exists to punish a fatultless party or to give the insurer a windfall through subrogation. ${ }^{103}$ Thus, the insurer must, under this statute, compensate the insured for loss without regard to the apportionment provisions, and the benefit from the compensation

99. Compare Law Reform (Frustrated Contracts) Act, 1943, 6 \& 7 Geo. 6, c. 40, \& $1(5)$, which provides that the court is not to consider insurance in making its apportionment. In the Parliamentary debate on the act, 128 H.L. Deb. (5th ser.) 144 (1043), Lord Nathan stated: "I am a little troubled by that provision because . . . if moncy rcceived on insurance is not to be taken into account, may it not be that to that extent this provision will enure to the advantage of the insurance company and not to the advantage, as was intended, of the party to the frustrated contract?" Viscount Simon, who introduced the act in the House answered: "[Subsection 1(5)] is intended to preserve the rights of insurance companies either by limiting the losses or giving subrogation rights; but I will look into it again in the light of what he [Lord Nathan] has said." 128 H.L. Dey. (5th ser.) 151 (1943). Apparently Viscount Simon and the House of Lords were unpersuaded by Lord Nathan. Lord Nathan's view, however, is adopted by the statute set out in text.

100. The typical case in which subrogation is not permitted occurs when, after risk has passed to the buyer under a sales contract, the item to be sold is destroyed. Many such cases involve real property. E.g., Godfrey v. Alcorn, $215 \mathrm{Ky} .465,284$ S.W. 1094 (1926) ; Wm. Skinner \& Sons Shipbuilding \& Dry-Dock Co. v. Houghton, $92 \mathrm{Md}$. 68, 84-90, 48 Atl. 85, 87-89 (1900) ; Dubin Paper Co. v. Insurance Co., $361 \mathrm{~Pa}$. 68, 85-92, 63 A.2d 85, $94-97$ (1949); see King, Subrogation Under Contracts Insuring Property, 30 Texas L. Rev. 62, 77 (1951). Cases involving personal property evidence less unatuimity. See In re Future Mfg. Corp., 165 F. Supp. 111 (N:D. Cal. 1958); Automatic Sprinkler Corp. of America v. Robinson Slagle Lumber Co., 147 So. 542 (La. Ct. App. 1933); Gillingham v. Phelps, 5 Wash. 2d 410, 105 P.2d 825 (1940). But see Cadillac Auto. Co. v. Fisher, 54 R.I. 264, 172 Atl. 393 (1934); Home Ins. Co. v. Bishop, 140 Me. 72,34 A.2d 22 (1943).

101. 80 U.S. (13 Wall.) 367 (1871).

102. See Note, 28 Colum. L. Rev. 202 (1928).

103. It has been suggested that its rates are not set in anticipation of recovery through subrogation. King, supra note 100, at 77; Note, 28 CoLun. L. REv. 202, 209 (1928). 
accrues to all parties who would have to assume part of the loss were there no insurance. Assume, for example, that a seller $A$ buys 1,000 dollars worth of widgets in reliance on a contract and immediately insures them. Upon discharge for destruction of the widgets, the insurer must pay $A$ the full 1,000 dollars although had there been no insurance, $A$ may have suffered only a 500 dollar loss after apportionment as provided for in section 8 . The insurer may not subsequently step into $A$ 's shoes and sue buyer $B$ for half the loss.

\section{Section 7. Restitution}

If, at the time a contract is discharged, the essential reliance cxpenses of one party have benefited another party, the bencfited party must pay the first party the value of the benefit received.

\section{COAIMENT}

Section 7, the first of two operative sections of this act, provides a traditional restitutionary remedy to be used in cases where it is necessary for one party to compensate another for benefit received before the total loss to all parties can be equitably apportioned. Benefit is defined in subsection 3(a) and discussed in the comment thereto. Methods for evaluating benefit are set forth in subsection $4(\mathrm{a})$ and the accompanying comment. The interrelation of section 7 and subsections $3(a)$ and $4(a)$ is illustrated by the following examples.

1. C contracts to build a wing on $O$ 's home. After $C$ has laid the foundation, the house and the new foundation are destroyed by earthquake. Under section 7, $O$ must pay for any benefit accruing to him from $C$ 's performance. Section 3 (a) indicates, however, that the foundation was not "benefit" because its value was "destroyed by the event occasioning discharge of the contract." $C$, therefore, cannot recover under section 7. His costs of performance are reliance expenses, treated as loss under section 5 and apportionable under sections $8(\mathrm{~b})$ or $(\mathrm{c})$.

2. Electrician $E$ contracts with eccentric millionaire $M I$ to replace all electric light fixtures in $M$ 's home with gas lights. After $E$ has removed the electric fixtures but before he has installed the gas lights, he dies, and his death discharges the contract. His estate sues for the value of what he has done. Was there benefit? Section 3(a) indicates that there was. Under that section benefit will be found if "the first party [has received] an actual gain of pecuniary value to the first party." Thus, if $M$, can have the job completed for less than the contract price, $M$ must pay for the value of $E$ 's work under section 7. How much must he pay? The method for evaluating benefit, as set forth in subsection 4(a), is market price, "or if there is no determinable market price, .. . the contract price less the amount a subsequent contractor would charge to complete the ends to be achieved by the contract." Removal of the electric light fixtures obviously added no market value to the home. Thus, market price is not a feasible method of evaluating benefit in this case, and the alternative standard must be used. If $M$ contracted to pay $E 1,000$ dollars for the 
whole job and another electrician will complete the job for 800 dollars, $M$ was benefited by $E$ 's work to the extent of 200 dollars, the sum that $M$ must pay $E$ 's estate under section 7 of this act.

\section{Section 8. Courses of Action Available to Court}

If one or more of the parties has incurred apportionable losses, as drfincd in section 5 of this act (and thus, not recoverable under section 7), in the absence of a contractual provision to the contrary, the court shall, as it dccms most just

(a) modify the provisions of the contract to reduce total loss and apportion the loss resulting after modification equitably among the partics; or

(b) apportion the loss equally among the parties except that

(1) in no case shall a party's loss after apportionment be greatcr than that party's predicted essential reliance expenses plus all losses that party actually incurred, and

(2) in no case shall a party be required to pay a second party for loss attributable to destroyed nonintegral property; or

(c) evaluate and apportion the loss in any manner it deems just. e.r. cept that

(1) in no case shall a party's loss after apportionment be greater than that party's predicted reliance expenses plus all losses that party' actually incurred, and

(2) in 120 case shall a party be required to pay a second party for loss attributable to destroyed nonintegral property.

\section{COMMENT}

This section sets forth three courses of action designed to provide a court with the power equitably to reduce and/or apportion loss as defined in section 5. A court must choose that course which produces the most equitable results under the circumstances of any particular case. Section 8(a) permits modification of contractual provisions; section 8(b) prescribes the standard formula for apportionment-equal division of loss among the parties. Section $8(\mathrm{c})$ allows the court, with certain limitations, to apportion and evaluate loss in any manner it deems just if an equal division would be inequitable.

Under 8(a), a court may modify contractual obligations if the modification will reduce the total loss suffered by the parties. It should be noted that this act does not prescribe the conditions under which a court may discharge full performance of a contract as burdensome. The extent to which modification will be utilized depends upon the scope of the substantive law of burdensome contracts. If, for example, discharge is limited to situations in which performance is objectively impossible, such as the destruction of a house which is the subject of a repair contract, modification will rarely be possible. The following examples, illustrating how a court might use the power of modification, assume 
that, in each case, the substantive law of the jurisdiction has evolved to permit discharge.

1. $A$ agrees to sell $B$ ten widgets at ten dollars per widget. Because of an unusual and unanticipated inflationary rise in the market, the cost of manufacturing widgets becomes ninety dollars per widget. $A$ began producing the widgets before the inflation and completes the manufacturing process after the inflation, thereby incurring an 800 dollar expense in reliance on the contract. $A$ now seeks to have a court discharge him from his duty to deliver widgets at the contract price. If the court discharges the contract, assuming that no one else will take these particular widgets, under section 8(b), the total apportionable loss of 800 dollars will be borne by both the parties. Under section 8(a), however, the court can raise the contract price and force $B$ to pay $A$ for the full manufacturing cost of the widgets because the resale price or the value to $B$ is such that forcing $B$ to pay 800 dollars will not place a loss on him.

2. Assume the same case as in example 1 above, but $B$ has contracted to resell the widgets to $C$ at 700 dollars. After modification of the contract between $A$ and $B, B$ must pay $A 700$ dollars. Under subsection 8 (a) the 100 dollar loss resulting after modification may be divided between $A$ and $B$. As a result of the modification the parties must together bear a 100 dollar, not an 800 dollar, loss.

Section 8(b) sets forth the formula for loss apportionment which it is assumed will be used in most cases. Section 8 (c) permits other than an equal split of loss when the circumstances of the case indicate either that it is more equitable to place more loss on one party than on another, or when there are reasons for ignoring one or more elements of apportionable loss. When a party, for example, is not enough at fault to be held liable for breach yet is in some sense a "wrongdoer," the court may deem it just to place all or most of the loss on him. Similarly, when incidental reliance expenses or integral property loss seem too remote from the contract, the court may not wish to consider them in the apportionment (see comment to section 5).

Under $8(b)$ and $8(\mathrm{c})$, the court will ordinarily order one party to pay over a sum of money to another. To prevent apportionment from being unreasonably burdensome, limitations on the amount of court-imposed loss must be provided for. Assume, for example, a discharged buyer-seller contract. Both parties are faultless, both are able to bear the loss, and no element of loss is too remotely identified with the contract to be apportionable. Under such circumstances, equitable apportionment would probably call for an equal split of loss. But the buyer may have incurred incidental reliance expenses far in excess of the amounts the seller would have had to spend in reliance on the contract. An equal split of total apportionable loss therefore would be inequitable, for the seller might be placed in the paradoxical position of losing more after discharge than he would have had he been successfully sued for breach or if he had completely performed and received nothing in return. Sections $8($ b) (1) and $8($ c) (1)-designed to avoid such inequities yet allow the court 
maximum leeway to apportion loss-provide respectively that no party shall suffer a loss after apportionment greater than his predicted essential reliance expenses plus other losses actually incurred or greater than his predicted reliance expenses plus other losses actually incurred. Different limitations are applicable to court apportionment under $8(\mathrm{~b})$ and 8 (c) because the two subsections have different purposes. Section 8 (c) gives the court broad discretion to apportion loss as it deems just. The limitation to predicted reliance expenses is designed to give the court maximum flexibility. Section 8 (b) provides an operational loss-apportionment formula designed to achieve fair results in most cases. To facilitate operational utility of the formula, the limitation on court-imposed loss is a party's predicted essential reliance expenses. A party's future essential reliance expenses will be easier to prove than his future essential and incidental reliance expenses.

An identical rationale underlies the limitations provided in sections $8(\mathrm{~b})(1)$ and $8(\mathrm{c})(1)$-that is, when a party spends or anticipates spending money, or anything else of value, in reliance on a contract, he risks losing it. Admittedly a party will rarely lose everything he has spent in reliance on a contract; nevertheless, the possibility of such a loss is the maximum risk a party undertakes. After a seller performs, for example, the buyer may abscond to Jamaica with the goods or become insolvent so that the seller receives a negligible dividend from the buyer's trustee in bankruptcy.

The following example illustrates how the predicted-expense provisions limit court-imposed loss. Suppose seller $A$ contracts to sell custom-made machines to buyer $B$ for 9,000 dollars. After $A$ has spent 6,000 dollars partially constructing the machines and $B$ has spent 12,000 dollars building foundations for the installation of the machines, $A$ 's plant is destroyed and the contract is discharged. The total apportionable loss, as calculated under section 5 , is 18,000 dollars (6,000 dollars for the machines plus 12,000 dollars for the foundations). Splitting the loss under section $8(\mathrm{~b})$, each party, in the absence of the limitaltions of 8 (b) (1), bears 9,000 dollars of loss. $A$ would, therefore, have to pay' $B$ 3,000 dollars. But before the court orders such a payment, it must determine whether 9,000 dollars is above the maximum loss $A$ may have imposed on him under $8(\mathrm{~b})(1)$. This subsection sets forth the predicted reliance expense limitation, which equals 6,000 dollars (which $A$ spent in reliance) plus 2,000 dollars (which it is assumed is the amount $A$ would have spent in essential reliance had the event occasioning discharge not arisen) or a total of 8,000 dollars. Since 8,000 dollars is the maximum loss $A$ may suffer and since he already suffered 6,000 dollars of it, he must pay $B 2,000$ dollars. Note that it is unnecessary to compute $B$ 's predicted essential reliance expenses. Since $B$ is the party who is going to be compensated, the court will impose no loss on him, and thus it is impossible for his loss to exceed his predicted essentinl reliance expenses plus losses actually incurred.

Sections 8(b) (2) and 8(c)(2) insure that no party is ever paid for his nonintegral property loss. Thus nonintegral property loss which enters into the section 5 computation of loss (see comment to section 5) may only be used 
by a party as a balance against the apportionable loss of another party. If $C$, for example, is in the midst of building a wing on $O$ 's home when the house is destroyed by flood (against which no one in $O$ 's community was insured) loss as computed by section 5 of this act would include the value of the work $C$ did (500 dollars) plus the value of $O$ 's house $(40,000$ dollars), or 40,500 dollars. Splitting this in half under $8(\mathrm{~b})$, each party should bear a 20,250 dollar loss, and $C$ should pay $O 19,750$ dollars. But $C$ does not have to compensate $O$ for such nonintegral property loss. On the other hand, $C$ bears his 500 dollar reliance loss and $O$ does not have to split it with him because of the disastrous misfortune $O$ suffered by the destruction of his house. If the circumstances of the case indicate that it would still be equitable to make $O$ share C's 500 dollar loss, in spite of the destruction of the home, this may be done under the broad discretionary provisions of subsection $8(\mathrm{c})$.

A final point is that under subsection 8(c) the court may not only apportion loss in any manner it sees fit, but it may evaluate loss in a different manner than that prescribed by section 4 of this act. Thus, if the court deems it just, integral property may be valued at reproduction cost and not original cost.

PhiLrp D. WeIssi

iThird-year-student, Yale Law School. 